\title{
Zinc in Infection and Inflammation
}

\author{
Nour Zahi Gammoh and Lothar Rink * \\ Institute of Immunology, Faculty of Medicine, RWTH Aachen University, University Hospital, Pauwelstrasse 30, \\ 52074 Aachen, Germany; nour.gammoh@rwth-aachen.de \\ * Correspondence: LRink@UKAachen.de; Tel.: +49-2418-080-208
}

Received: 29 April 2017; Accepted: 11 June 2017; Published: 17 June 2017

\begin{abstract}
Micronutrient homeostasis is a key factor in maintaining a healthy immune system. Zinc is an essential micronutrient that is involved in the regulation of the innate and adaptive immune responses. The main cause of zinc deficiency is malnutrition. Zinc deficiency leads to cell-mediated immune dysfunctions among other manifestations. Consequently, such dysfunctions lead to a worse outcome in the response towards bacterial infection and sepsis. For instance, zinc is an essential component of the pathogen-eliminating signal transduction pathways leading to neutrophil extracellular traps (NET) formation, as well as inducing cell-mediated immunity over humoral immunity by regulating specific factors of differentiation. Additionally, zinc deficiency plays a role in inflammation, mainly elevating inflammatory response as well as damage to host tissue. Zinc is involved in the modulation of the proinflammatory response by targeting Nuclear Factor Kappa B (NF- $\mathrm{kB})$, a transcription factor that is the master regulator of proinflammatory responses. It is also involved in controlling oxidative stress and regulating inflammatory cytokines. Zinc plays an intricate function during an immune response and its homeostasis is critical for sustaining proper immune function. This review will summarize the latest findings concerning the role of this micronutrient during the course of infections and inflammatory response and how the immune system modulates zinc depending on different stimuli.
\end{abstract}

Keywords: zinc; infection; inflammation; homeostasis

\section{Introduction}

Zinc is a nutritionally fundamental trace element and is the second most abundant trace metal in the human body after iron. The influence of zinc on human health was first observed and described by Prasad et al. in the 1960s [1]. Zinc research has come a long way since then; its significance as a structural component in many proteins and its participation in numerous cellular functions is now well established. Such functions include, but are not limited to, cell proliferation and differentiation [2], RNA and DNA synthesis [3], as well as cell structures and cell membrane stabilization [4]. Its multifaceted role in the regulation of the immune system is particularly interesting and will be discussed in more detail in this review [5]. Consequently, zinc's implication in an array of functions demonstrates how a defect in nutritional absorption may lead to the manifestation of various diseases.

Zinc is involved in many metabolic and chronic diseases such as: diabetes, cancer (esophageal, oral small cell carcinoma, breast cancer), and neurodegenerative diseases. There is also strong evidence between zinc deficiency and several infectious diseases such as malaria, HIV, tuberculosis, measles, and pneumonia [6].

\section{Zinc and Nutrition}

The total zinc content in the human body amounts to $2-4 \mathrm{~g}$, with a plasma concentration of $12-16 \mu \mathrm{M}$ [2]. Albeit it is a small plasma pool, it is rapidly exchangeable and mobile. Sufficient daily intake of zinc is necessary to maintain a steady state because, unlike iron, the body has no specialized 
zinc storage system. The highest concentrations of zinc are found in the muscles, bones, skin, and liver $[7,8]$.

Recommended daily intake of zinc depends on several factors such as age, sex, weight, and phytate content of diet. Those recommended values differ in each country. The US Food and Nutrition Board recommended intake of $11 \mathrm{mg} /$ day and $8 \mathrm{mg} /$ day for adult males and females, respectively [9]. While the German Society of Nutrition's recommendation comprised of $10 \mathrm{mg} /$ day and $7 \mathrm{mg} /$ day for adult males and females, respectively [10]. Both the World Health Organization (WHO) and the European Food Safety Authority (EFSA) consider the inhibitory effect of dietary phytate on zinc absorption when setting the recommended zinc intake values. WHO categorizes diets according to their potential absorption efficiency of zinc, per phytate-zinc molar ratio, into 3 groups; high $(<5)$, moderate (5-15), and low ( $>15)$ zinc bioavailability [11]. Whereas EFSA provides different zinc reference recommendations for diets containing phytate intake levels of 300, 600, 900, and $1200 \mathrm{mg} /$ day [12].

As mentioned, zinc bioavailability depends on the composition of the diet. Non-digestible plant ligands such as phytate, some dietary fibers, and lignin chelate zinc and inhibit its absorption. Other factors that influence the absorption of zinc are calcium and iron. Zinc is present in many food groups and its concentration and bioavailability varies considerably. Foods with the highest zinc concentration include red meat, some shellfish, legumes, fortified cereals, and whole grains [9]. Zinc from animal sources has higher bioavailability compared to zinc sourced from plant products. People who abstain from eating red meats, vegetarians, vegans, and people living in developing country who rely mainly on plant-based foods are at higher risk of developing zinc deficiency due to inadequate zinc intake [13]. Oral zinc supplements are readily available but not all offer the same zinc bioavailability. Zinc bound to amino acids such as aspartate, cysteine, and histidine shows the highest absorption concentration, followed by zinc chloride, sulfate, and acetate, whereas zinc oxide show the lowest bioavailability [14].

According to the $\mathrm{WHO}$, zinc deficiency is currently the fifth leading cause of mortality and morbidity in developing countries. It is estimated that it affects about one-third of the world's population. Worldwide, zinc deficiency accounts for approximately $16 \%$ of lower respiratory tract infections, $18 \%$ of malaria, and $10 \%$ of diarrheal diseases. While severe zinc deficiency is rare, mild to moderate deficiency is more common worldwide $[15,16]$.

\section{Zinc Homeostasis}

\subsection{Zinc Transporters}

There are two major protein families that mammalian zinc transporters belong to. The first group of transporter are ZIP (Zrt/Irt-like proteins), which are responsible for transporting zinc into the cytosol from either extracellular space or from intracellular compartments. There are 14 ZIP transporters, designated as Solute Carrier family SLC39A1-A14. The second group of 10 transporters are ZnT (Zinc transporters), which are designated as SLC30A1-A10. They generally transport zinc out of the cytosol into extracellular space or intracellular organelles such as zincosomes. Zincosomes are vesicles that can sequester high levels of zinc [17-19].

Each of the ZIP and ZnT transporters show tissue specificity and developmental and stimulus responsive expression patterns. On a cellular and subcellular level, they are also localized in specific compartments. Both transporter families respond to various stimuli such as zinc deficiency and excess by displaying specific changes in cellular localization and protein stability [20].

There are many zinc transporter mutations that are reported to be involved in inherited diseases. Most notably, a mutation in ZIP4 (SLC39A4), which is an intestinal zinc transporter, is responsible for the rare lethal autosomal-recessive inherited zinc deficiency disease, acrodermatitis enteropathica (AE). $\mathrm{AE}$ is characterized by severe dermatological manifestations, gastrointestinal disturbances, weight loss, growth retardation, male hypogonadism, and high susceptibility to infections among other clinical features. Complete recovery occurred after high-dose zinc supplementation [21]. In addition to AE, 
there is another genetic disease associated to mutations in ZIP transporters. Mutations in SLC39A13, encoding ZIP13, cause a novel subtype of Ehlers-Danlos Syndrome (EDS). EDS is a spectrum of connective tissue disorders caused by mutations affecting collagen synthesis and modification [22].

There are also some genetic diseases affecting the $\mathrm{ZnT}$ family. One example is a mutation influencing ZnT2. A substitution of a histidine with an arginine at amino acid 54 (H54R) in the human SLC30A2 gene causes a defect in zinc secretion. The H54R mutation of ZnT2 is autosomal dominant as women who are heterozygous for the allele present the phenotype of reduced zinc production in the breast milk during lactation. Infants that are exclusively breast-fed suffer from zinc deficiency due to low zinc levels in the breast milk, which in turn predisposes them to multiple infections. Zinc deficiency symptoms can be alleviated by oral zinc supplementation to the nursing babies [23].

Expression modulation of ZIPs and ZnTs during inflammatory processes has been documented. Intracellular zinc requirements are altered during an inflammatory event or when an invading pathogen gains access to the cell. For instance, in an allergic inflammation mouse model, expression of zinc transporters was altered, including increases in ZIP1 and ZIP14 and decreases in ZIP4 and ZnT4 [24]. Furthermore, zinc deprivation of phagocytosed Histoplasma capsulatum by sequestration into the Golgi apparatus is controlled by ZnT4 and ZnT7 and uptake of extracellular zinc is controlled by ZIP2 [25]. The role of zinc transporters during inflammation and infection is under active investigation and more will be revealed of how those transporters influence zinc homeostasis in different conditions.

\subsection{Metallothioneins and Other Zinc Binding Proteins}

Metallothioneins (MTs) are cysteine-rich 6-7 kDa proteins that bind metal ions such as zinc [26]. Up to $20 \%$ of intracellular zinc is bound to MTs, and can be rapidly released. They can form a complex with up to 7 zinc ions. There are four different MT classes; MT- 1 and MT-2 are ubiquitous throughout the body, their main function is to maintain cellular zinc homeostasis and chelate heavy metals to reduce cytotoxicity and lower their intracellular concentrations, and due to their reactive oxygen species (ROS) scavenging properties, they help protect against several types of environmental stress. MT-3 and MT-4 expression is restricted to a cell type-specific pattern, with MT-3 predominantly found in the brain and MT-4 is primarily located in stratified epithelial tissues [20,27].

In addition to MTs, there are other zinc binding proteins that act as a storage system and control the release of zinc. Albumin binds around $80 \%$ of all plasma zinc and is thought to act as a major zinc transporter. Albumin modulates zinc uptake into certain cell types, such as endothelial cells. These cells co-transport albumin-bound zinc via a specific receptor-mediated pathway. Albumin has several metal-binding sites that are specific for different metal ions, for instance, site A binds specifically to zinc at high affinity. However, the fatty acid content of albumin influences metal binding, particularly during conditions of increased free fatty acid mobilization such as after exercise. Zinc-binding capacity may be reduced in such conditions when about four fatty acids may be bound to albumin. Even though zinc albumin complexes do not dissociate as easily as other zinc-protein complexes, they are still considered to have rapid exchange kinetics and contribute to the modulation of free zinc in the plasma [28].

Furthermore, the S100 protein family, which consists of more than 20 members, is composed of EF-hand calcium regulated proteins, and they are distributed in a cell-specific, tissue-specific, and cell cycle-specific manner in humans and other vertebrates. S100 proteins have diverse functions ranging from calcium buffering, intracellular functions such as modulating enzyme activities and secretions, nuclear functions such as apoptosis and transcription, and extracellular activities related to secretion and chemotaxis, among other functions [29]. S100 proteins are also regulated by zinc and several members show higher affinity towards zinc compared to calcium such as the case with S100A3. The zinc-binding site in S100B, S100A6, S100A7, S100A8/A9, S100A12, and S100A15 consist of either three histidine residues and one aspartate or four histidine residues and is distinct from the calcium binding sites in the EF-hands, while S100A2, S100A3, and S100A4 have cysteine-containing 
zinc-binding sites [30]. A brief description of the role of some S100 protein in nutritional immunity will be mentioned later.

$\alpha 2$-macroglobulin (A2M) is another zinc-binding protein which is an inhibitor of matrix metalloproteases (MMPs) and it is required to remove proteolytic potential, when MMPs increase, forming A2M-proteinase complexes. It has a very high affinity to zinc, where zinc is required for the activation of $\mathrm{A} 2 \mathrm{M}$ and also for the binding of $\mathrm{A} 2 \mathrm{M}$ with cytokines [31].

The cytokine interleukin 6 (IL6) induces the expression of MT and A2M and consequently reduces zinc availability. IL-6 is released during the acute phase of an inflammatory response. This mechanism is beneficial to the acute immune response, however, a long-term decrease in zinc availability may contribute to pathological processes in conditions of chronic inflammation (e.g., diabetes and dementia). IL6, MT, and A2M expression increase in old age and impaired zinc availability contributes to immunosenescence. A mutation in the IL6 promoter up-regulates its expression leading to increased MT, low plasma zinc, impaired innate immunity and increased risk of Alzheimer disease [32].

\section{Zinc and Immunity}

Many organs are affected by zinc deficiency, especially the immune system which is markedly susceptible to changes of zinc levels. It seems that every immunological event is influenced by zinc somehow. The immune response involves two mechanisms; innate and adaptive immunity. The first cells to encounter invading pathogens and eliminate them are the cells of the innate immunity. Polymorphonuclear cells (PMNs), macrophages $(\mathrm{M} \phi)$, and natural killer cells (NK) are some of those first responders. PMN chemotaxis and phagocytosis are reduced during zinc deficiency, whereas zinc supplementation has the opposite effect. After phagocytosis, pathogens are destroyed by the activity of nicotinamide adenine dinucleotide phosphate (NADPH) oxidases which has been shown to be inhibited by both zinc deficiency and excess [33,34]. Alternatively, PMN can kill pathogens by releasing neutrophil extracellular traps (NETs). These matrices of DNA, chromatin, and granule proteins can capture extracellular bacteria [35]. Chelating free zinc abolishes NET formation was observed in vitro. Moreover, before macrophages can mature into tissue resident cells, circulating monocytes must be attracted to the target tissues and adhere to endothelial cells. In vitro, this process of adhesion is augmented by zinc. Zinc deficiency increases the production of proinflammatory cytokines, such as interleukins IL-1 $\beta$, IL-6, and tumor necrosis factor (TNF)- $\alpha$. Recognition of major histocompatibility complex (MHC) class I by NK cells and the lytic activity of NK cells is influenced by zinc depletion. In terms of the adaptive immune response, zinc deficiency causes thymic atrophy and subsequent T-cell lymphopenia as well as reduction of premature and immature B cells, and consequently antibody production is also reduced [36]. The following sections will delve deeper into how zinc influences immune cells and their mediators during inflammation and infection.

It is worth mentioning that most zinc deficiency studies have been conducted on animal models and various cell culture types. Since zinc does not have major storage depot in the body, zinc deficiency is easily and rapidly produced. As mentioned previously, severe zinc deficiency is rare but mild to moderate deficiency is more prevalent. It remains a challenging task to attribute certain clinical manifestations to mild to moderate zinc deficiency, particularly because depletion of zinc from tissue is usually accompanied by deficiencies in other nutrients. This can be further rationalized by understanding the influence of zinc deficiency on food intake; this effect was observed in rats that were either starved or fed zinc deficient diets resulting in reduced weight and metabolic activity among other indicators. Thus common zinc deficiency symptoms can be attributed to either low zinc or to reduced overall nutrient intake [37]. However, that does not undermine the vital role zinc plays in the immune system.

\section{Zinc in Inflammation}

Inflammation is a natural process required to protect the host from tissue damage and infections, which leads to the resolution of the inflammatory response and the restoration of homeostasis. 
However, sometimes the inflammation does not resolve and later becomes chronic, leading to loss of tissue function [38]. This section will review how the body mounts an inflammatory response and how zinc influences those processes.

\subsection{NF- $\kappa B$ and Other Signalling Pathways}

Proper modulation of inflammatory pathways is required to achieve adequate response to various stimuli such as stress, free radicals, cytokines, or bacterial and viral antigens. One of the main inflammatory pathways is the nuclear factor kappa-light-chain-enhancer of activated B cells (NF- $\kappa \mathrm{B}$ ) signaling pathway. It regulates the genes controlling apoptosis, cell adhesion, proliferation, tissue remodeling, the innate and adaptive immune responses, inflammatory processes, and cellular-stress responses. Subsequently, it influences the expression of proinflammatory cytokines such as TNF- $\alpha$, IL-1 $\beta$, IL-6, IL-8, and MCP (monocyte chemoattractant protein)-1. NF-kB is one of the most versatile regulators of gene expression [39].

The NF- $\kappa$ B protein family in mammalian cells consists of five members, RelA (p65), RelB, c-Rel,

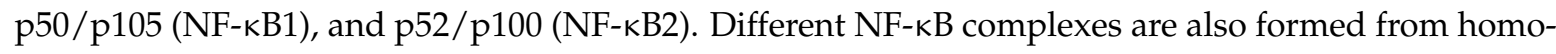
and heterodimers. Non-active NF- $\mathrm{B}$ complexes are typically found in the cytoplasm, where they are bound to and silenced by a family of inhibitory proteins known as inhibitors of NF- $\kappa B$ (I $\kappa$ Bs). There

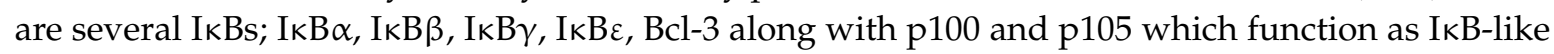
proteins that inhibit their NF- $\mathrm{kB}$-subunit dimeric partners, p50 and p52, respectively. Activation of NF- $\kappa B$ requires the phosphorylation of I $\kappa$ Bs by the I $\kappa B$ kinase (IKK) complex, which degrades the I $\mathrm{B}$ and releases NF- $\mathrm{BB}$ and allows it to translocate freely to the nucleus so it can induce targeted gene expression $[39,40]$.

There are several conflicting studies regarding the effect of zinc on this process. In vitro studies using different cell types and zinc concentrations as well as the impact of chelating agents have made it obvious that the influence of zinc cannot be interpreted using a unilateral approach [41]. For instance, a study by Haase et al. has revealed that zinc is necessary for the activation of lipopolysaccharide (LPS)-induced NF- $\mathrm{BB}$ signaling pathway, whereas chelating zinc with membrane permeable zinc specific chelator TPEN ( $N, N, N^{\prime}, N^{\prime}$-tetrakis-(2-pyridyl-methyl) ethylenediamine) completely blocked this pathway [42]. On the other hand, there is a growing body of literature that supports the role of zinc as a negative regulator of NF- $\mathrm{KB}$ signaling pathways. There are several inhibitory mechanisms that have been suggested. One of the major inhibitory mechanisms relies on how zinc affects the expression of protein A20. A20 is a zinc-finger protein that is recognized as an anti-inflammatory protein which also negatively regulates tumor necrosis factor receptor (TNFR)- and toll like receptor (TLR)-initiated NF- $\mathrm{BB}$ pathways (Figure 1). During TNFR signaling, A20 is able to deubiquitinate receptor interacting protein 1 (RIP1), which prevents its interaction with NF- $\mathrm{B}$ essential modulator IKK $\gamma$. It also inhibits TLR signaling by removing polyubiquitin chains from TNF receptor associated factor 6 (TRAF6). Although the deubiquitinase activity of A20 remains unchanged by zinc chelator [19], Prasad et al. demonstrated that the induction of A20 mRNA and generation of the protein in pre-monocytic, endothelial, and cancer cell is zinc-dependent [43]. Additionally, zinc supplementation was able to downregulate inflammatory cytokines by decreasing gene expression of IL- $1 \beta$ and TNF- $\alpha$ through upregulation of mRNA and DNA-specific binding for A20, subsequently inhibiting NF- $\kappa$ B activation [44]. 


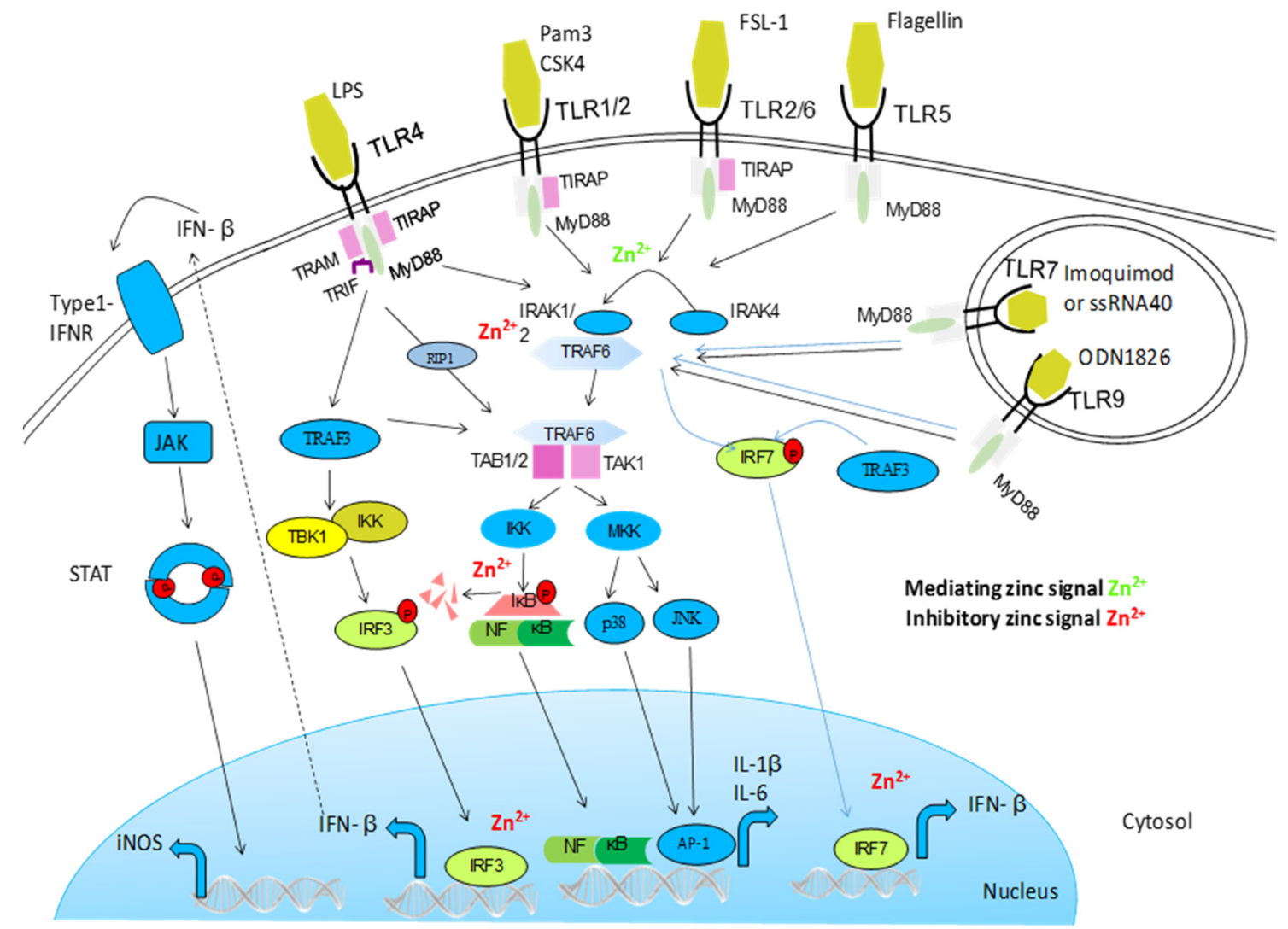

Figure 1. Activation of Toll-like receptor (TLR) signaling pathways is mediated by a complex array of proteins. When TLRs bind ligands, dimerization of the ectodomain of TLRs is induced, bringing their cytoplasmic Toll/IL-1R domains together, resulting in the recruitment of intracellular adapter proteins and initiation of downstream signaling events. Following this, the Toll-IL-1-resistence (TIR) domains of TLRs engage TIR domain-containing adaptor proteins (either myeloid differentiation primary-response protein 88 (MYD88) or TIR domain-containing adaptor protein inducing IFN $\beta$ (TRIF) and TRIF-related adaptor molecule (TRAM)). This in turn stimulates downstream signaling pathways that involve interactions between IL-1R-associated kinases (IRAKs) and the adaptor molecules TNF receptor-associated factors (TRAFs), and that lead to the activation of the mitogen-activated protein kinases (MAPKs) JUN N-terminal kinase (JNK) and p38, and to the activation of transcription factors. Two groups of transcription factors are activated downstream of TLR signaling; nuclear factor- $\mathrm{KB}(\mathrm{NF}-\mathrm{KB})$ and interferon-regulatory factors (IRFs). This TLR signaling pathway leads to the induction of proinflammatory cytokines. Zinc influences this pathway on multiple levels. It augments MyD88-dependent signaling whereas inhibiting TRIF-mediated activation of IRF3/7. It has been shown that zinc inhibits IRAK thereby inhibiting further signal transductions. In vitro, zinc also directly impaired LPS-induced IKK activity [45].

There are several studies that have examined the influence of zinc on A20-mediated NF- $\kappa \mathrm{B}$ inhibition [46-48]. Moreover, zinc inhibits NF- $\kappa B$ activation in the DNA nuclear binding levels by increasing the expression of peroxisome proliferator-activated receptor $\alpha$ (PPAR- $\alpha$ ), which is a mediator for lipoprotein metabolism, inflammation, and glucose homeostasis. PPAR- $\alpha$ increase leads to the down-regulation of inflammatory cytokines and adhesion molecule [49]. Additionally, zinc acts as an inhibitor of cyclic nucleotide phosphodiesterase (PDE). When PDE is inhibited, cyclic nucleotide cGMP (Cyclic guanosine monophosphate) is elevated leading to the activation of PKA (protein kinase A) and subsequent inhibition of NF-кB [50]. Similarly, zinc can bind to a zinc finger-like motif found on protein kinase $C(P K C)$ and inhibit PMA-mediated PKC translocation to the membrane. When this occurs in mast cells, NF- $\kappa$ B activity is indirectly inhibited [51]. Those mentioned studies demonstrates 
how zinc influences inflammation via NF- $\mathrm{kB}$ signaling pathways through several mechanisms and at many levels. Figures 2 and 3 provide more details on how zinc influences several pro- and anti-inflammatory pathways.

\section{Pro-inflammatorySignalling \\ Pathways}

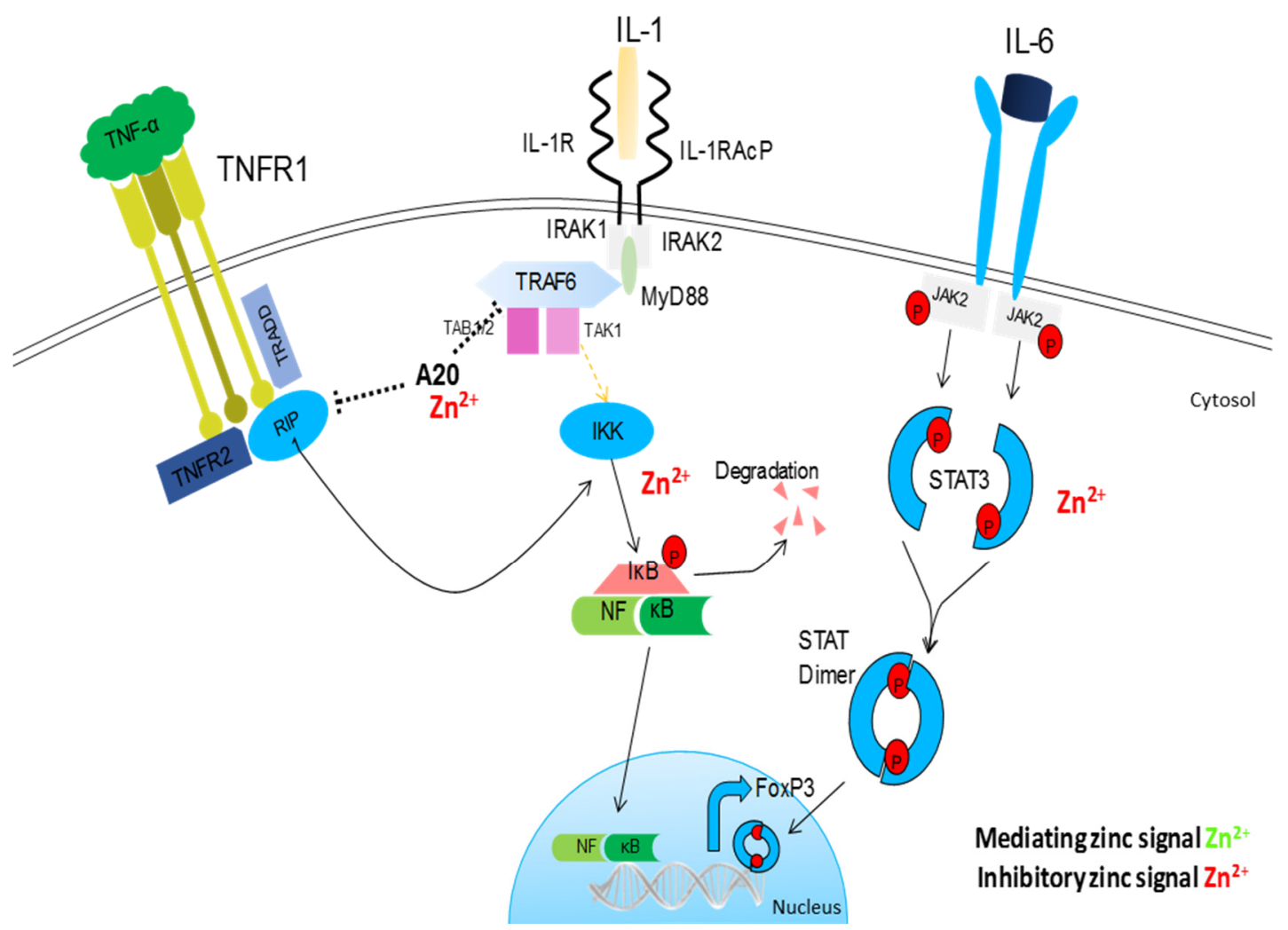

Figure 2. Pro-inflammatory signaling pathway influences by zinc. Similar to TLR signaling, IL-1, and TNF-R signaling pathways converge on a common I $\kappa B$ kinase complex that phosphorylates the NF- $\kappa B$ inhibitory protein, resulting in the release of NF- $\mathrm{KB}$ and its translocation to the nucleus. Zinc prevents the dissociation of NF- $\mathrm{KB}$ from its corresponding inhibitory protein, thus preventing the nuclear translocation of NF- $\mathrm{KB}$ and inhibiting subsequent inflammation. Zinc also inhibits IL-6-mediated activation of STAT3. Zinc acts as anti-inflammatory element influencing major pro-inflammatory signaling pathways.

Zinc can simultaneously modulate inflammation through TLR signaling at different levels and pathways [45]. TLRs are single, membrane-spanning, noncatalytic receptors which are expressed on many cells such as macrophages and dendritic cells and can distinguish and be activated by structurally conserved molecules derived from microbes. In monocytes, it has been observed that TLR4 activation initiates zinc-mediated signaling in a MyD88 (Myeloid differentiation primary response gene 88) and TRIF independent manner. Zinc has been shown to influence cellular signal transduction by inhibition of several dephosphorylating enzymes like protein tyrosine phosphatase (PTPs), cyclic nucleotide phosphodiesterases, and dual specificity phosphatases. Therefore, an alternative mechanism was purposed in which zinc acts as a permissive signal. In this mechanism, the level of intracellular free zinc regulates the rate of dephosphorylation, and thereby the signal intensity of phosphorylation-dependent signaling [19]. 


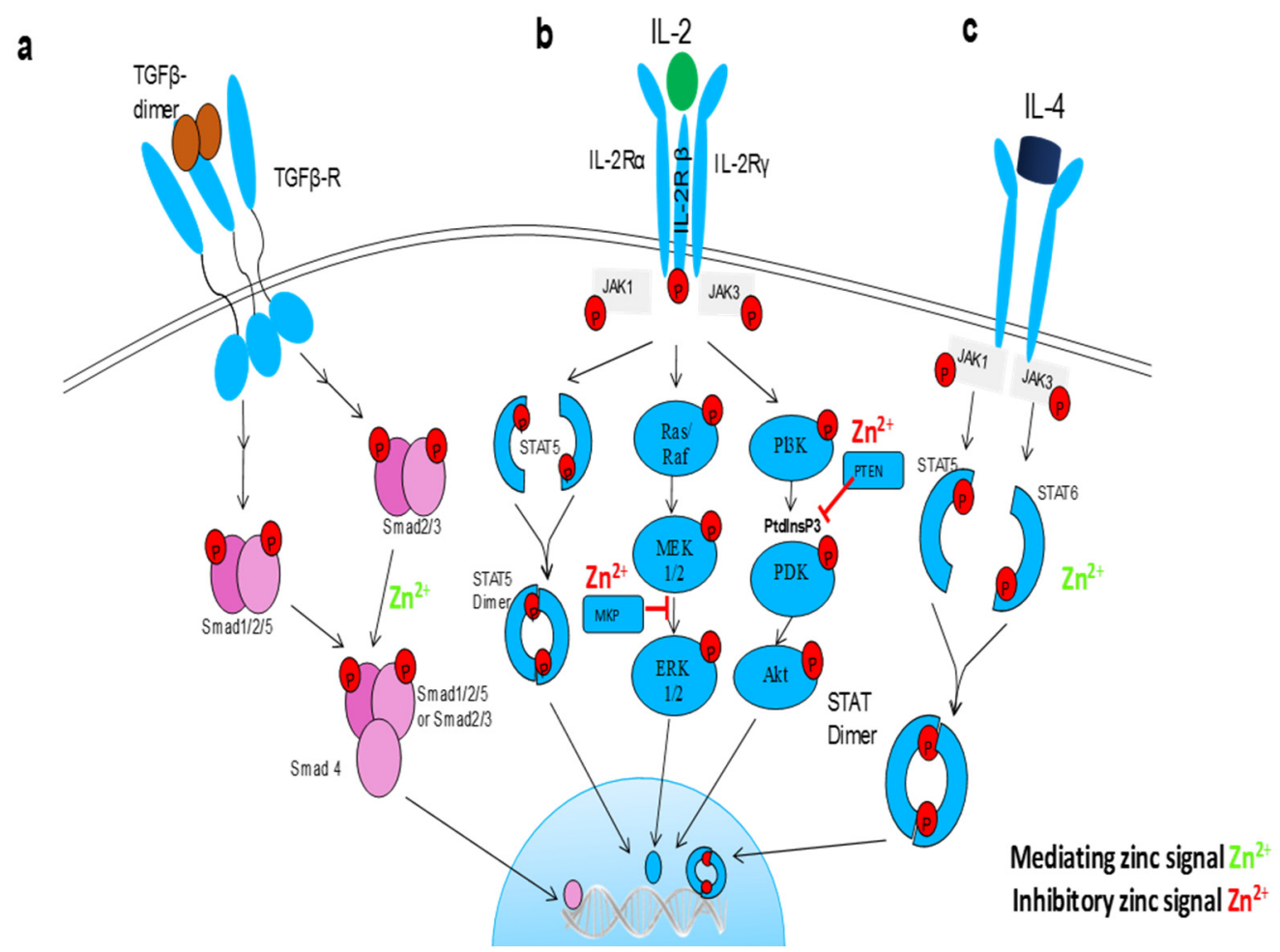

Figure 3. Anti-inflammatory signaling pathways influenced by free zinc. (a) TGF $\beta$ signaling is dependent on a dynamic on and off switch in Smad activity. Free zinc is a cofactor in Smad proteins and promote Smad 2/3 nuclear translocation and transcriptional activity. (b) zinc regulates IL-2 signaling pathway via blocking MAP kinase phosphatase (MKP) in extracellular signal-regulated kinases (ERK) $1 / 2$ pathways and Phosphatase and tensin homologue (PTEN) which opposes phosphoinositide 3-kinase (PI3K) function in PI3k/Akt pathway. (c) free zinc phosphorylates STAT6 and promotes translocation of STAT dimers into the nucleus, hence promote the anti-inflammatory effects of Il-4.

Zinc also plays a role in modulating the apoptotic and inflammatory processes of caspases, which are a family of endoproteases. Apoptosis is an intricate process where intracellular components are dismantled in a controlled fashion whilst avoiding inflammation and damage to the surrounding cells. Dysregulation in apoptosis influences the pathogenesis of many diseases such as AIDS, diabetes mellitus, autoimmune diseases, malignancies, and most prominently, neurodegenerative disorders. Thus, understanding the regulatory factors involved in this process is crucial for developing therapeutic strategies [52]. There are several conflicting results showing how zinc can be anti- or pro-apoptotic depending on the zinc concentration used. Moreover, it has been observed that both zinc deficiency and supplementation induced apoptosis in the same cellular model [53]. There are two anti-apoptotic mechanisms of action exerted by zinc on caspase-dependent processes. Firstly, zinc suppresses some of the signaling pathways that lead to caspase activation and apoptosis by limiting the damage caused by free oxygen radicals and other toxins. Secondly, zinc directly affects apoptotic caspase enzymes. Influence of zinc on limiting free radicals will be discussed in the following section. With regard to the direct effect zinc has on caspases, many studies established the inhibitory role of zinc on apoptotic caspases 3, 6, 7, 8, and 9 [54-56]. Caspase-3 is particularly interesting due to its dominant role in the apoptotic pathway. Zinc is a potent inhibitor of caspase- 3 with an $\mathrm{IC}_{50}$ below $10 \mathrm{nM}$ [57]. Zinc containing compounds such as ziram (a zinc-containing dithiocarbamate) caused degradation of pro-caspase- 1 which is a precursor of the inflammatory caspase-1 [58]. Active caspase- 1 cleaves 
pro-IL-1 $\beta$ and pro-IL-18, which facilitates the secretion of these proinflammatory cytokines [59]. This indicated that zinc can also modulate caspase-controlled inflammatory processes.

Recent findings have established that zinc metabolism and its role in immune function are directly linked to zinc transporter function. This is demonstrated by ZIP8 which functions as a critical negative feedback regulator. When inflammation starts, NF- $\mathrm{KB}$ directly activates the expression of ZIP8, which then localizes to the plasma membrane, thereby mediating $Z n$ uptake. When zinc enters the cytosol via ZIP8 it goes on to inhibit IKK $\beta$ kinase activity, which leads to the attenuation of the pro-inflammatory response [60].

\subsection{Oxidative Stress}

Under non-pathological conditions, cells produce ROS during cellular respiration. However, excessive production of ROS and the decreased rate of its neutralization and removal by antioxidant defense mechanisms lead to an imbalance between oxidants and antioxidants which results in oxidative stress [61]. Accumulation of those free radicals leads to cell and tissue damage. Oxidative stress is responsible for the development of many chronic diseases such as cancer, cardiovascular disease, atherosclerosis, hypertension, ischemia/reperfusion injury, diabetes mellitus, neurodegenerative diseases (Alzheimer's disease and Parkinson's disease), rheumatoid arthritis, and ageing [62].

Within the cell, there are several sites and processes responsible for ROS production, these include; mitochondrial electron transport chain, peroxisomal long-chain fatty acid oxidation, and respiratory burst primarily through activation of NADPHs, which are plasma membrane-associated enzymes. Other enzymes generate ROS during enzymatic reaction cycles, such enzymes are cytochrome P450 monooxygenase, nitric oxide synthase (NOS), xanthine oxidase, cyclooxygenase (COX), and lipoxygenase (LOX). Apart from those endogenous sources of free radicals, there are also exogenous or environmental sources of ROS. Air pollutants, tobacco smoke, ionizing and nonionizing radiations, foods and drugs, as well as xenobiotics can all contribute to oxidative stress [63]. Heavy metals such as lead, arsenic, mercury, chromium, and cadmium; organic solvents; and pesticides are common exogenous sources of ROS [64].

In order to neutralize and remove excess ROS, cells have endogenous non-enzymatic and enzymatic antioxidant defense mechanisms. Non-enzymatic antioxidants include glutathione (GSH), thioredoxin (Trx), and melatonin. While Antioxidant enzymatic mechanisms involve enzymes, such as superoxide dismutase (SOD), glutathione peroxidase (GPx), glutathione reductase (GR), catalase (CAT), and heme oxygenase (HO). Exogenous antioxidants include vitamin $\mathrm{C}$, vitamin $\mathrm{E}$, carotenoids including vitamin $\mathrm{A}$, polyphenols including flavonoids and minerals such as zinc, copper, manganese, iron, and selenium $[63,65]$.

Zinc has several antioxidant effects. It is a cofactor of the $\mathrm{Cu} / \mathrm{Zn}-\mathrm{SOD}$ enzyme, which catalyzes the dismutation of superoxide radical $\left(\mathrm{O}_{2}{ }^{-}\right)$into the less harmful $\mathrm{O}_{2}$ and $\mathrm{H}_{2} \mathrm{O}_{2}$, which is then detoxified by CAT and GPx. It also inhibits NADPH oxidases, causing reduced generation of ROS. Furthermore, zinc induces the production of MTS, which are excellent ROS scavengers due to the high cysteine content [66]. Stabilization of protein sulfhydryls against oxidation by zinc is another mechanism by which zinc hinders the oxidative processes. Zinc binds directly to the thiol group, creates steric hindrance by binding close to the sulfhydryl group in the protein, and binds to other sites leading to conformational changes in the protein. This all results in the reduced activity of sulfhydryl [67]. Moreover, zinc antagonizes redox-active transition metals such as copper and iron that catalyze formation of free radicals, primarily through Fenton reactions. Those transition metals form complexes with cellular components, such as nucleotides, glucose, and citrates for iron and carbohydrates, DNA and enzymes for copper. When the metal is complexed, it becomes trapped and reacts with $\mathrm{H}_{2} \mathrm{O}_{2}$ and forms reactive hydroxyl radical $\left(\mathrm{HO}^{\bullet}\right)$. This leads to lipid peroxidation, DNA and protein damage, and subsequent severe tissue damage. Zinc is able to replace copper and iron and reduce the localized oxidative injury [68]. 
Zinc supplementation of healthy human subjects reduced the oxidative stress-related by-products malondialdehyde (MDA), 4-hydroxyalkenals (HAE), and 8-hydroxydeoxyguanine in the plasma [44]. This effect was also seen with elderly subjects who usually have lower plasma zinc concentration compared to younger people. Supplementation with zinc has reduced oxidative stress markers and lowered inflammatory cytokines and infection incidence [69]. Involvement of oxidative stress in other processes is discussed in more detail elsewhere [70].

\subsection{Zinc Status and Inflammatory Cytokines}

Zinc can influence the production and signaling of numerous inflammatory cytokines in a variety of cell types. Plasma zinc concentrations rapidly decline during acute phase response to different stimuli such as stress, infection, and trauma. Consequently, zinc is shuttled into cellular compartments, where it is utilized for protein synthesis, neutralization of free radicals, and to prevent microbial invasion. This redistribution of zinc during inflammatory events seems to be mediated by cytokines. Several studies have demonstrated how patients with acute illnesses present with hypozincemia along with elevated cytokine production [71,72].

Chronic inflammation is characterized by increased levels of inflammatory cytokine production. Some conditions are associated with chronic inflammation such as obesity, where patients with lower zinc dietary intake present with lower plasma and intracellular zinc concentrations along with upregulated gene expression of IL- $1 \alpha$, IL-1 $\beta$, and IL- 6 compared to patients with higher zinc intake [73].

The effect of zinc deficiency and supplementation is being reported regularly in in vitro and in vivo models. Cell specific responses and varying zinc dosage plays an important role in determining the outcome when subjecting cells to zinc depletion or supplementation. Various study models have been used. There are some noteworthy examples, for instance, the study mentioned above involving elderly subjects revealed that the elderly have significantly lower plasma zinc and higher ex vivo generation of inflammatory cytokines. Zinc supplementation partially reversed the levels of many inflammatory cytokines [69]. Yet zinc supplementation is not always beneficial, adding zinc at very high concentrations $(>100 \mu \mathrm{M})$ increases cytokine production in some cell types, this was seen in human peripheral blood mononuclear cells (PBMCs) harvested from healthy adults [74] and in human promonocytic HL-CZ cells [75]. As mentioned previously, zinc deficiency induces production of IL-1 $\beta$. This was seen in LPS-stimulated PBMCs from zinc-deficient adults compared to their zinc-sufficient counterparts [76]. This observation was confirmed through studying the epigenetic mechanisms that are implicated during zinc deficiency and it was reported that long term zinc deprivation promoted changes of the chromatin structures of IL-1 $\beta$ and TNF $\alpha$ promoters enabling the expression of both genes [77]. Additionally, phytohemagglutinin (PHA)-induced production of IL-2 was reduced in PBMCs of zinc-deficient patients with head and neck cancer and in zinc-deficient healthy volunteers [78]. IL-2 and IL-2R $\alpha$ mRNA were also reduced in zinc deficient elderly people [79]. Similarly, inducing deficiency in healthy men via a zinc restricted diet $(4.6 \mathrm{mg} /$ day for 10 weeks) led to a reduction of PHA-stimulated IL-2R production [80]. Furthermore, IL-6 production in zinc-deficient elderly subjects was increased [81]. These observations were later confirmed via DNA methylation profile characterization, which showed that zinc deficiency induced a progressive demethylation of the IL6 promoter in THP1 cells that correlated with increased IL6 expression [82].

Cytokines are produced by different types of cells, primarily by $\mathrm{T}$ lymphocytes and macrophages. The influence of zinc on these cells may explain the observed effect zinc has on cytokine production. Zinc deficiency affects immune cells in several ways. It reduces thymulin activity, which is required for the maturation of T-helper cells (Th), it causes an imbalance between Th1 and Th2 cells which decrease recruitment of T naïve cells and percentage of cytotoxic T cells $[83,84]$. It also lowers the cell lytic activity of NK cells [85]. During zinc deficiency, there is also reduced production of IFN- $\gamma$ and IL-2, which are products of Th1 cells, while the production of IL-4, IL-6, and IL-10 (products of Th2 cells) remain unchanged [86]. On the other hand, zinc excess (50-100 $\mu \mathrm{M})$ inhibits T cell activity which is 
demonstrated by the suppression of IL-1 $\beta$-stimulated IFN- $\gamma$ expression [87]. This shows how both zinc deficiency and increased zinc levels influence T-cell function. Additionally, regulatory T cells (Treg) are induced and stabilized in zinc-supplemented mixed lymphocyte culture (MLC), in lymphocytes from patients allergic to pollen [88] and in experimental autoimmune encephalomyelitis (EAE) [89]. Furthermore, zinc enhances the capacity of TGF $\beta 1$ to induce Treg cells [90,91]. However, the capacity of zinc to induce Tregs is dependent on the activation status of the cells. Activated zinc-supplemented $\mathrm{T}$ cells are driven to differentiate to Treg, whereas resting T cells are pushed to Th1 response [89]. Hence, the influence of zinc is expansive yet specific to each cell type.

\section{Zinc in Infection}

\subsection{Nutritional Immunity}

Nutritional immunity is a process by which the host organism sequesters trace minerals during an infection so it can be of limited availability to pathogens. It was first described for iron but has now been extended to other trace elements. Zinc is an essential trace element for both host and pathogens. Pathogens require zinc for survival, propagation and disease establishment. This prompts a competitive process between the host and the invading pathogens. There are three mechanisms by which the host is able to compete for zinc and achieve a zinc limited environment for the pathogen, however, some pathogens have developed tactics to overcome some of those mechanisms [5,92].

On a systematic level, zinc distribution in the body is altered. This mainly involves the small pool of free zinc that is unbound within plasma as $99.9 \%$ of zinc remains inside cells and cannot be directly accessed by pathogens. During an infection, plasma zinc levels are markedly reduced. This is achieved by several approaches, but primarily involves the secretion of inflammatory cytokines such as IL-6 that upregulates expression of ZIP14 in hepatocytes which leads to the accumulation of zinc bound to metallothionein in the liver [93]. Furthermore, zinc concentrations can be altered on an extracellular level through the release of some antimicrobial peptides from the S100 family. Several cell types secrete different peptides, keratinocytes secrete S100A7 that can kill Escherichia coli by sequestering zinc [94]. Additionally, neutrophils also secrete calprotectin (a heterodimer of S100A8 and S100A9). It can inhibit the growth of Staphylococcus aureus by sequestering zinc as well [95]. As mentioned previously, neutrophils also release NETs, in which they cast out DNA, chromatins, and granular proteins to capture and kill microorganisms [35]. Calprotectin is also released in very high concentrations during NETosis, where it is either incorporated into NET or in the surrounding fluids. On an intracellular level, macrophages have evolved two opposing strategies to kill phagocytosed pathogens. Macrophages can deprive Histoplasma capsulatum of zinc by reducing the phagosome zinc content [25]. On the other hand, they kill Mycobacterium tuberculosis by intoxicating it with excess amounts of zinc and copper [96].

Some pathogens have developed defense strategies against several of those mechanisms. For example, Neisseria meningitidis uses a high affinity zinc uptake receptor ZnuD which allows it to escape NET-mediated nutritional immunity [97]. It also responds to zinc deprivation by expressing $\mathrm{CbpA}$, which is an outer membrane protein that acts as a receptor for calprotectin and enables $N$. meningitides to acquire zinc bound to calprotectin. N. meningitidis effectively undermines an important defense mechanism used by the host and utilizes it in its favor [98]. Yersinia pestis utilizes the siderophore yersiniabactin $(\mathrm{Ybt})$ as a zincophore, and ZnuABC, which is the high-affinity zinc transporter found in bacteria and fungi, to acquire zinc and develop a lethal infection in a septicemic plague mouse model [99]. Salmonella typhimurium can also overcome calprotectin-mediated zinc chelation by expressing ZnuABC, thereby allowing it to compete with commensal bacteria and thrive in the inflamed gut [100].

Although low zinc is associated with an impaired immune system and poor prognosis in conditions such as sepsis, supplementation during sepsis was not beneficial, whereas prophylactic zinc administration showed some positive results [101]. In contrast, administering zinc via lozenges 
at concentrations of $\geq 75 \mathrm{mg}$ /day reduced the duration of common cold symptoms in healthy individuals [102]. It is worth mentioning that the decision to administer zinc during an infection must take into account the risks of creating a zinc microenvironment that is more favorable for pathogen growth, meanwhile downgrading the efforts carried out by the innate system to reduce free zinc. This only demonstrates the needs for more research to investigate and understand the therapeutic potentials of zinc for infectious diseases.

Despite zinc being recognized as a crucial factor for the proper functioning of the immune system, increased susceptibility to infections and other immune dysfunctions could be the consequence of one or more nutrient deficiencies. The same dietary factors leading to deficiency of one micronutrient often cause deficiency of other micronutrients. Additionally, supplementation of one micronutrient in high doses may exacerbate the status of other micronutrients, which can be seen in the case of iron supplementation impairing zinc uptake. Furthermore, excess supplementation of either zinc or copper influences the tightly controlled ratio of those two metals. Supplementation with high doses of zinc for prolonged periods lead to copper deficiency [53]. Also, altered zinc and copper homeostasis is implicated in several conditions, for example, high copper/zinc ratio was observed in the elderly, particularly those with neurodegenerative disorders $[103,104]$. The copper/zinc ratio maybe considered a biomarker for mortality in the elderly population [105], which further emphasizes the importance of understanding the complex interplay between different nutrients and their collective influence on health. Maintaining the homeostasis of micronutrients and vitamins is fundamental for a healthy immune response and overall wellness of the body. However, the interaction between micronutrients must be explored further in order to design supplementation interventions that target multiple deficiencies.

Tables 1-3 provide an accumulative record of selected publications on zinc supplementation trails. The influence of zinc on viral (Table 1), bacterial (Table 2), and parasitic (Table 3) infections depends on many factors that include, but not limited to; zinc status at baseline measurement, zinc supplementation concentration and frequency, zinc species and age. Results must be interpreted cautiously and analytically. A continuous joint effort between members of the scientific community who conduct such clinical trials will only shed more light on the influence zinc has on infectious diseases and how it can be utilized further. 
Table 1. Zinc supplementation and viral diseases (updated from [106]).

\begin{tabular}{|c|c|c|c|c|c|c|}
\hline Disease & Zinc Species & Zinc Dosage & Period & Participation & Effect of Zinc Supplementation & Reference \\
\hline \multirow{2}{*}{ Common cold } & \multicolumn{4}{|c|}{ more than 12 different studies, analyzing the therapeutic effects of zinc } & $\begin{array}{l}\text { variable results, reduced duration of symptoms if } \\
\text { administered within } 24 \mathrm{~h} \text { of onset }\end{array}$ & [107] \\
\hline & zinc sulfate & 15 mg daily & 7 months & $\begin{array}{l}100(\mathrm{Z}) \\
100(\mathrm{P})\end{array}$ & $\begin{array}{l}\text { lower mean number of colds demonstrating the prophylactic } \\
\text { effect of zinc }\end{array}$ & [108] \\
\hline \multirow{11}{*}{ HIV/AIDS } & Not specified & $\begin{array}{l}12 \mathrm{mg} \text { for women } \\
\text { and } 15 \mathrm{mg} \text { for } \\
\text { men/day }\end{array}$ & 18 months & $\begin{array}{l}115(\mathrm{Z}) \\
116(\mathrm{P})\end{array}$ & $\begin{array}{l}\text { no effect on viral load. four-fold reduction in the likelihood of } \\
\text { immunological failure. Reduced the rate of diarrhea by more } \\
\text { than half. No significant difference in mortality }\end{array}$ & [109] \\
\hline & Chelated zinc & 15 mg daily & 12 months & $\begin{array}{l}\text { Low: } 5(\mathrm{Z}) / 7(\mathrm{P}) \\
\text { Normal: } 8(\mathrm{Z}) / 10(\mathrm{P})\end{array}$ & $\mathrm{CD}^{+}{ }^{+}$cell count significantly increased & [110] \\
\hline & Zinc sulfate & 20 mg daily & 24 weeks & $\begin{array}{l}26(Z) \\
26(P)\end{array}$ & $\begin{array}{l}\text { no effect on the increase in CD4\%, decrease in viral load, } \\
\text { anthropometric indices, and morbidity profile in HIV-infected } \\
\text { children started on ART }\end{array}$ & [111] \\
\hline & Zinc sulfate & $45.5 \mathrm{mg}$ daily & 1 month & $\begin{array}{l}29(\mathrm{Z}) \\
28(\mathrm{P})\end{array}$ & $\begin{array}{l}\text { increase or stabilization in body weight; increase in plasma } \\
\text { zinc levels, CD } 4^{+} \mathrm{T} \text { cells and plasma active zinc-bound } \\
\text { thymulin; reduced or delayed frequency of opportunistic } \\
\text { infections due to Pneumocystis jiroveci and Candida, not to } \\
\text { Cytomegalovirus and Toxoplasma }\end{array}$ & [112] \\
\hline & Zinc gluconate & $\begin{array}{l}45 \mathrm{mg} \text { three time } \\
\text { daily }\end{array}$ & 15 days & $\begin{array}{l}5(Z) \\
5(C)\end{array}$ & $\begin{array}{l}\text { increased zinc concentrations in red blood, HLA-DR + cells, } \\
\text { stimulation of lymphocyte transformation and phagocytosis of } \\
\text { opsonized zymosan by neutrophils }\end{array}$ & [113] \\
\hline & Zinc sulfate & 10 mg daily & 6 months & $\begin{array}{l}44(\mathrm{Z}) \\
41(\mathrm{P})\end{array}$ & no effect on HIV viral load; decreased morbidity from diarrhea & [114] \\
\hline & Zinc sulfate & $50 \mathrm{mg}$ daily & 1 month & $\begin{array}{l}31(\mathrm{Z}) \\
34(\mathrm{P})\end{array}$ & $\begin{array}{l}\text { no improvements in immune responses to tuberculosis, } \\
\text { CD4/CD8 ratio, lymphocyte subsets, and viral load }\end{array}$ & [115] \\
\hline & Zinc sulfate & 25 mg daily & 6 months & $\begin{array}{l}200(Z) \\
200(P)\end{array}$ & $\begin{array}{l}\text { when supplemented to pregnant HIV-positive women, no } \\
\text { effect on birth outcomes or T-lymphocyte counts, and negative } \\
\text { effects on hematological indicators }\end{array}$ & [116] \\
\hline & \multirow[t]{2}{*}{ Zinc sulfate } & \multirow[t]{2}{*}{25 mg daily } & \multirow[t]{2}{*}{6 months } & $\begin{array}{l}200(Z) \\
200(P)\end{array}$ & increased risk of wasting & \multirow[t]{2}{*}{ [117] } \\
\hline & & & & $\begin{array}{l}50(\mathrm{Z}) \\
50(\mathrm{P})\end{array}$ & no effect on viral load & \\
\hline & Zinc gluconate & 50 mg daily & 6 days & $\begin{array}{l}44(\mathrm{Z}) \\
45(\mathrm{P})\end{array}$ & $\begin{array}{c}\text { no improvements in antibody responses to a pneumococcal } \\
\text { conjugate vaccine }\end{array}$ & [118] \\
\hline
\end{tabular}


Table 1. Cont.

\begin{tabular}{|c|c|c|c|c|c|c|}
\hline Disease & Zinc Species & Zinc Dosage & Period & Participation & Effect of Zinc Supplementation & Reference \\
\hline \multirow{4}{*}{$\begin{array}{l}\text { hepatitis C } \\
\text { virus }\end{array}$} & Not specified & $10 \mathrm{mg}$ & 60 days & $\begin{array}{l}26(\mathrm{Z}+6400 \mathrm{mg} / \text { day } \\
\text { Branched-chain } \\
\text { amino acids }) \\
27(\mathrm{P})\end{array}$ & $\begin{array}{l}\text { BCAA-to-tyrosine ratio (BTR) and zinc levels were } \\
\text { significantly increased compared with the placebo group. } \\
\text { supplementation reduced the serum } \alpha \text {-fetoprotein AFP levels } \\
\text { in patients who had elevated serum AFP levels at baseline }\end{array}$ & [119] \\
\hline & Polapre-zinc & $150 \mathrm{mg}$ & 48 weeks & $\begin{array}{l}11(\mathrm{Z}) \\
12(\mathrm{C})\end{array}$ & $\begin{array}{l}\text { serum alanine aminotransferase (ALT) level is lower in zinc } \\
\text { group compared to control group. HCV RNA disappeared in } \\
\text { all patients in the zinc group and in } 80 \% \text { control patients at } \\
48 \text { week. Polaprezinc supplementation decreased plasma } \\
\text { thiobarbituric acid reactive substances and prevented the } \\
\text { decrease of polyunsaturated fatty acids of erythrocyte } \\
\text { membrane phospholipids }\end{array}$ & [120] \\
\hline & Polapre-zinc & $17 \mathrm{mg}$ twice a day & 24 weeks & $\begin{array}{l}40(\mathrm{Z}) \\
35(\mathrm{C})\end{array}$ & $\begin{array}{l}\text { zinc supplementation increases serum zinc levels and } \\
\text { improves the response to IFN- } \alpha \text { therapy }\end{array}$ & [121] \\
\hline & Zinc gluconate & 50 mg daily & 6 months & $\begin{array}{l}18(\mathrm{Z}) \\
35(\mathrm{P}) \\
20(\mathrm{C})\end{array}$ & $\begin{array}{c}\text { increased serum zinc levels; decreased incidences of } \\
\text { gastrointestinal disturbances, body weight loss, } \\
\text { and mild anemia }\end{array}$ & [122] \\
\hline
\end{tabular}

Table 2. Zinc supplementation and bacterial infectious diseases (updated from [106]).

\begin{tabular}{|c|c|c|c|c|c|c|}
\hline Disease & Zinc Species & Zinc Dosage & Period & Participation & Effect of Zinc Supplementation & Reference \\
\hline \multirow[b]{2}{*}{ Diarrhea } & \multicolumn{4}{|c|}{ multiple different studies } & decreased duration, severity and occurrence of diarrhea & [123] \\
\hline & Not specified & 20 mg daily & 14 days & $\begin{array}{c}41(\mathrm{Z}) \\
39(\text { micronutrient } \\
\text { combination * + Vit A) } \\
44(\mathrm{Z}+\mathrm{Vit} \mathrm{A}) \\
43(\mathrm{P})\end{array}$ & $\begin{array}{l}\text { supplementation with a combination of micronutrients and vitamins was not } \\
\text { superior to zinc alone, confirming clinical benefit of zinc in children } \\
\text { with diarrhea }\end{array}$ & [124] \\
\hline
\end{tabular}


Table 2. Cont.

\begin{tabular}{|c|c|c|c|c|c|c|}
\hline Disease & Zinc Species & Zinc Dosage & Period & Participation & Effect of Zinc Supplementation & Reference \\
\hline \multirow{6}{*}{$\begin{array}{l}\text { Respiratory tract } \\
\text { infections }\end{array}$} & Zinc sulfate & 20 mg daily & 5 months & $\begin{array}{l}134(\mathrm{Z}) \\
124(\mathrm{P})\end{array}$ & reduced acute lower respiratory tract infection morbidity & [125] \\
\hline & zinc gluconate & 10 mg daily & 60 days & $\begin{array}{l}48(\mathrm{Z}) \\
48(\mathrm{P})\end{array}$ & $\begin{array}{l}\text { reduced episodes of acute lower respiratory infections and severe acute lower } \\
\text { respiratory infections. Increased infection free days }\end{array}$ & [126] \\
\hline & Zinc oxide & 5 mg daily & 12 months & $\begin{array}{l}162(Z) \\
167(C)\end{array}$ & $\begin{array}{l}\text { decreased incidence of upper respiratory tract infections and diarrhoeal } \\
\text { disease episodes }\end{array}$ & [127] \\
\hline & zinc gluconate & 10 mg daily & 6 months & $\begin{array}{l}298(\mathrm{Z}) \\
311(\mathrm{P})\end{array}$ & increased plasma zinc levels; decreased episodes of infection & [128] \\
\hline & Zinc acetate & $10 \mathrm{mg}$ twice a day & 5 days & $\begin{array}{l}76(\mathrm{Z}) \\
74(\mathrm{P})\end{array}$ & increased serum zinc levels and recovery rates from illness and fever in boys & [129] \\
\hline & Zinc sulfate & 15 mg daily & 6 months & $\begin{array}{l}40(\mathrm{Z}) \\
40(\mathrm{P})\end{array}$ & $\begin{array}{c}\text { increased plasma retinol concentrations; earlier sputum conversion and } \\
\text { resolution of X-ray lesion area }\end{array}$ & [130] \\
\hline Tuberculosis & zinc sulfate & 220 mg daily & 18 months & $8(Z)$ & $\begin{array}{c}\text { reduced dose of clofazimine; withdrawal of steroids; toleration of dapsone; } \\
\text { reduced incidence and severity of erythema nodosum leprosum; gradual } \\
\text { decrease in the size of granuloma; gradual increase in the number of } \\
\text { lymphocytes }\end{array}$ & [131] \\
\hline \multirow{3}{*}{$\begin{array}{l}\text { Lepromatous } \\
\text { leprosy }\end{array}$} & zinc sulfate & 220 mg daily & 18 months & $\begin{array}{l}15(\mathrm{Z}) \\
10(\mathrm{P})\end{array}$ & $\begin{array}{c}\text { decreased erythema, edema, and infiltration; regrowth of eyebrows; reduced } \\
\text { bacterial index of granuloma; increased serum zinc levels, neovascularization, } \\
\text { and endothelial cell proliferation }\end{array}$ & [132] \\
\hline & Zinc acetate & $\begin{array}{l}200 \mathrm{mg} \text { twice a } \\
\text { day }\end{array}$ & 13 weeks & $\begin{array}{l}17(\mathrm{Z}) \\
10(\mathrm{P}) \\
10(\mathrm{C})\end{array}$ & $\begin{array}{l}\text { increased serum zinc levels and delayed hypersensitivity reactions; decreased } \\
\text { size of skin nodules; disappearance of erythema; regrowth of eyebrows }\end{array}$ & [133] \\
\hline & zinc sulfate & 220 mg daily & 4 months & $40(\mathrm{Z})$ & $\begin{array}{l}\text { improvements on frequency, duration, and severity of erytheme nodosum } \\
\text { leprosum reactions; reduction in steroid requirement }\end{array}$ & [134] \\
\hline \multirow{4}{*}{ Shigellosis } & zinc acetate & $\begin{array}{l}1.3 \mathrm{mg} / \mathrm{kg} \text { three } \\
\text { times a day }\end{array}$ & 1 month & $\begin{array}{l}16(\mathrm{Z}) \\
16(\mathrm{P})\end{array}$ & $\begin{array}{l}\text { increased intestinal mucosal permeability and better nitrogen absorption; } \\
\text { increased serum zinc and alkaline phosphatase activity }\end{array}$ & [135] \\
\hline & zinc acetate & 20 mg daily & 2 weeks & $\begin{array}{l}28(\mathrm{Z}) \\
28(\mathrm{P})\end{array}$ & $\begin{array}{l}\text { increased serum zinc levels, lymphocyte proliferation in response to } \\
\text { phytohemagglutinin and plasma invasion plasmid-encoded antigen-specific } \\
\text { IgG titers }\end{array}$ & [136] \\
\hline & zinc acetate & 20 mg daily & 2 weeks & $\begin{array}{l}28(\mathrm{Z}) \\
28(\mathrm{P})\end{array}$ & $\begin{array}{l}\text { increased serum zinc levels, serum shigellacidal antibody titers, } \mathrm{CD} 20^{+} \text {cells, } \\
\text { and CD } 20^{+} \mathrm{CD} 38^{+} \text {cells }\end{array}$ & [137] \\
\hline & Not specified & 20 mg daily & 2 weeks & $\begin{array}{l}14(\mathrm{Z}) \\
16(\mathrm{C})\end{array}$ & $\begin{array}{l}\text { faster recovery from acute illness. Increased mean body weight. Fewer } \\
\text { episodes of diarrhoea }\end{array}$ & [138] \\
\hline $\begin{array}{l}\text { Helicobacter } \\
\text { pylori infection }\end{array}$ & polapre zinc & $\begin{array}{l}150 \text { mg twice a } \\
\text { day }\end{array}$ & 7 days & $\begin{array}{l}33(\mathrm{Z}) \\
28(\mathrm{C})\end{array}$ & $\begin{array}{l}\text { administration of zinc together with antimicrobial therapy increased cure rate } \\
\text { of Helicobacter pylori infection compared with antibiotic treatment alone }\end{array}$ & [139] \\
\hline
\end{tabular}

Z-zinc, P-placebo, C-control; Diarrhea and respiratory infections can be caused by nonbacterial pathogens. The mentioned studies do not specific the causative agent; * micronutrient combination: zinc, $20 \mathrm{mg}$; iron, $10 \mathrm{mg}$; copper, $2 \mathrm{mg}$; selenium, $40 \mathrm{mg}$; vitamin B12, $1.4 \mathrm{mg}$; folate, $100 \mathrm{mg}$. 
Table 3. Zinc supplementation and parasites (updated from [103]).

\begin{tabular}{|c|c|c|c|c|c|c|}
\hline Disease & Zinc Species & Zinc Dosage & Period & Participation & Effect of Zinc Supplementation & Reference \\
\hline \multirow{6}{*}{ Malaria } & Not specified & $\begin{array}{l}10 \mathrm{mg} \\
6 \text { times/week }\end{array}$ & 6 months & $\begin{array}{l}74(\mathrm{Z}+1 \text { single dose } \\
\text { of 200,000 IU Vit A) } \\
74(\mathrm{P})\end{array}$ & $\begin{array}{l}\text { significant decrease in the prevalence malaria. Lower malaria } \\
\text { episodes. Time to first malaria episode was longer. } 22 \% \text { fewer fever } \\
\text { episodes than the placebo group }\end{array}$ & [140] \\
\hline & Zinc gluconate & $\begin{array}{c}10 \mathrm{mg} \\
6 \text { times/week }\end{array}$ & 46 weeks & $\begin{array}{l}136(\mathrm{Z}) \\
138(\mathrm{P})\end{array}$ & reduction in Plasmodium falciparum-mediated febrile episodes & [141] \\
\hline & $\begin{array}{l}\text { Zinc acetate/zinc } \\
\text { gluconate }\end{array}$ & $\begin{array}{l}70 \mathrm{mg} \text { twice a } \\
\text { week }\end{array}$ & 15 months & $\begin{array}{l}55(\mathrm{Z}) \\
54(\mathrm{P})\end{array}$ & $\begin{array}{l}\text { not statistically significant trend towards fewer malaria episodes; no } \\
\text { effect on plasma and hair zinc, diarrhea, and respiratory illness }\end{array}$ & [142] \\
\hline & Zinc sulfate & $\begin{array}{c}12.5 \mathrm{mg} \\
6 \text { times/week }\end{array}$ & 6 months & $\begin{array}{l}336(\mathrm{Z}) \\
344(\mathrm{P})\end{array}$ & increased serum zinc levels; reduced prevalence of diarrhea & [143] \\
\hline & Zinc sulfate & 20 or $40 \mathrm{mg}$ daily & 4 days & $\begin{array}{l}473(\mathrm{Z}) \\
483(\mathrm{P})\end{array}$ & $\begin{array}{l}\text { increased plasma zinc, no effect on fever, parasitemia, or } \\
\text { hemoglobin concentration }\end{array}$ & [144] \\
\hline & Zinc sulfate & 20 mg daily & 7 months & $\begin{array}{l}191(Z) \\
189(P)\end{array}$ & $\begin{array}{l}\text { no significant effect on P. vivax incidence; significantly reduced } \\
\text { diarrhea morbidity }\end{array}$ & [145] \\
\hline
\end{tabular}




\subsection{Zinc as a Critical Component of the Membrane Barrier}

Zinc may contribute to the host defense by maintaining the membrane barrier structure and function. This is very crucial in sites like the lung and intestine that become continuously exposed to a myriad of pathogens and noxious agents. Zinc deficiency may contribute to the severity of infectious diseases and mortality in malnourished children. In case of diarrhea, which is the leading cause of death globally among children under five years of age, zinc supplementation has been shown to reduce the severity and duration of symptoms [146]. WHO recommends zinc supplementation of $20 \mathrm{mg}$ per day for 10-14 days for the management of diarrhea [147]. Several studies have examined the influence of zinc depletion and supplementation on the permeability of the endothelial cell barrier. The intestinal epithelium barrier consists of intercellular junctional complexes between neighboring cells that provide a continuous seal around the apical region of the cells. These complexes are composed of several units, including the tight junctions (TJ) and adherens junctions (AJ), that form circumferential zones of contact between adjacent cells. E-cadherin is the main transmembrane adhesion molecule localized at the $\mathrm{AJ}$ and its binding to $\beta$-catenin is fundamental for appropriate $\mathrm{AJ}$ organization. Zinc depletion disrupted the TJ and AJ through several mechanisms. One way zinc affected structural proteins was by enhancing the degradation of E-cadherin and $\beta$-catenin [148]. This was also seen in zinc-deprived airway epithelial cells, where there was accelerated proteolysis of E-cadherin and $\beta$-catenin leading to increased leakage across the monolayer of upper and alveolar lung epithelial cultures [149]. Hypozincemia may induce uncontrolled neutrophil migration through the disrupted junctional complexes by inducing chemokine production. Exacerbated inflammation may develop and lead to mucosal damage which further contributes to intestinal and lung disease. On the other hand, zinc supplementation has been seen to preserve and restore membrane function and structure [148].

Zinc is also an integral part of the epidermal and dermal tissues, where it acts as a stabilizer of cell membranes and as an essential cofactor in numerous transcription factors and enzymes. This includes the zinc-dependent matrix metalloproteinases that enhance autodebridement and keratinocyte migration during wound repair. Moreover, zinc confers resistance to epithelial apoptosis through cytoprotection against reactive oxygen species and bacterial toxins possibly through antioxidant activity of the cysteine-rich metallothioneins [150]. Hence, zinc deficiency may result in delayed wound healing, particularly in the elderly with impaired nutritional status. Delayed wound healing in the elderly constitutes a major clinical and economic challenge, especially as the aging population grows [151]. Topical zinc therapy has shown promising results in enhancing wound healing due to zinc's role in reducing superinfections and necrotic material by augmenting local defense systems and collagenolytic activity, as well as promoting epithelialization of wounds [150]. Thus, utilizing topical zinc treatments to support wound healing provides a therapeutic advantage and enhances quality of life.

\subsection{Peptidoglycan Regulation Proteins (PGLYRPs)}

Another beneficial effect that zinc has on secretory molecules is how it is involved in the bactericidal activity of peptidoglycan recognition proteins (PGRPs or PGLYRPs). Those innate immunity pattern recognition molecules have effector functions and are expressed in either PMN molecules or in the skin, eyes, salivary glands, throat, tongue, esophagus, stomach, and intestine. Along with other antimicrobial peptides they protect the body from pathogen at the first line of exposure [152]. The activity of PGLYRPs against Gram-positive and Gram-negative bacteria is dependent on free zinc [153].

\section{Conclusions}

Zinc is a multipurpose metal that is vital for the growth and function of all cells. The immune system is especially affected by the modification of zinc homeostasis. Achieving an optimal immune 
response to different stimuli and avoiding damage of tissues and organs is a delicate balance that relies, amongst other factors, on the regulation of zinc in extracellular and intracellular compartments.

It would be highly beneficial to attain a standard by which zinc supplementation can be administered in different conditions, however, creating such standard might be challenging due to many conflicting findings on various cell types, experimental models, and zinc concentrations, and due to the lack of a good biomarker for zinc status in the body. Nevertheless, resolving zinc deficiency and the adverse manifestations associated with it can be achieved through adequate diet and supplementation.

Acknowledgments: L.R. is a member of Zinc-Net. N.Z.G. is supported by a scholarship from the German Academic Exchange Service (DAAD).

Author Contributions: N.Z.G. wrote the manuscript. L.R. made critical revisions.

Conflicts of Interest: The authors declare no conflict of interest.

\section{References}

1. Prasad, A.S.; Miale, A., Jr.; Farid, Z.; Sandstead, H.H.; Schulert, A.R. Zinc metabolism in patients with the syndrome of iron deficiency anemia, hepatosplenomegaly, dwarfism, and hypogonadism. J. Lab. Clin. Med. 1963, 61, 537-549. [PubMed]

2. Rink, L.; Gabriel, P. Zinc and the immune system. Proc. Nutr. Soc. 2000, 59, 541-552. [CrossRef] [PubMed]

3. Vallee, B.L.; Falchuk, K.H. The biochemical basis of zinc physiology. Physiol. Rev. 1993, 73, 79-118. [PubMed]

4. Maret, W.; Li, Y. Coordination dynamics of zinc in proteins. Chem. Rev. 2009, 109, 4682-4707. [CrossRef] [PubMed]

5. Haase, H.; Rink, L. Multiple impacts of zinc on immune function. Metall. Integr. Biomet. Sci. 2014, 6, 1175-1180. [CrossRef] [PubMed]

6. Maret, W. Zinc and Human Disease. In Interrelations between Essential Metal Ions and Human Diseases; Sigel, A., Sigel, H., Sigel, R.K., Eds.; Springer: Dordrecht, The Netherlands, 2013; pp. 389-414.

7. Mills, C.F. (Ed.) Zinc in Human Biology. In Physiology of Zinc: General Aspects; Springer: London, UK, 1989. [CrossRef]

8. Favier, A.; Favier, M. Effects of zinc deficiency in pregnancy on the mother and the newborn infant. Rev. Fr. Gynecol. Obstet. 1990, 85, 13-27. [PubMed]

9. Otten, J.J.; Hellwig, J.P.; Meyers, L.D. (Eds.) Dietary Reference Intakes: The Essential Guide to Nutrient Requirements; The National Academies Press: Washington, DC, USA, 2006. Available online: https:/ / doi.org/10.17226/11537 (accessed on 7 July 2017).

10. Deutsche Gesellschaft für Ernährung. Österreichische Gesellschaft für Ernährung; Schweizerische Gesellschaft für Ernährungsforschung; Schweizerische Vereinigung für Ernährung; Referenzwerte für die Nährstoffzufuhr: Bonn, Germany, 2016. (In German)

11. World Health Organization (WHO). Trace Elements in Human Nutrition and Health; World Health Organization: Geneva, Switzerland, 1996.

12. EFSA Panel on Dietetic Products Nutrition and Allergies. Scientific Opinion on Dietary Reference Values for zinc. EFSA J. 2014, 12. [CrossRef]

13. King, J.C.; Brown, K.H.; Gibson, R.S.; Krebs, N.F.; Lowe, N.M.; Siekmann, J.H.; Raiten, D.J. Biomarkers of Nutrition for Development (BOND)—Zinc Review. J. Nutr. 2016, 146, 858S-885S. [CrossRef] [PubMed]

14. Brieger, A.; Rink, L. Zink und Immunfunktionen. Ernährung Medizin 2010, 25, 156-160. [CrossRef]

15. Sandstead, H.H. Zinc Deficiency. Am. J. Dis. Child. 1991, 145, 853-859. [CrossRef] [PubMed]

16. World Health Organisation. The World Health Report; World Health Organization: Geneva, Switzerland, 2002.

17. Wellenreuther, G.; Cianci, M.; Tucoulou, R.; Meyer-Klaucke, W.; Haase, H. The ligand environment of zinc stored in vesicles. Biochem. Biophys. Res. Commun. 2009, 380, 198-203. [CrossRef] [PubMed]

18. Kambe, T.; Hashimoto, A.; Fujimoto, S. Current understanding of ZIP and ZnT zinc transporters in human health and diseases. Cell. Mol. Life Sci. 2014, 71, 3281-3295. [CrossRef] [PubMed]

19. Haase, H.; Rink, L. Functional significance of zinc-related signaling pathways in immune cells. Annu. Rev. Nutr. 2009, 29, 133-152. [CrossRef] [PubMed] 
20. Kimura, T.; Kambe, T. The Functions of Metallothionein and ZIP and ZnT Transporters: An Overview and Perspective. Int. J. Mol. Sci. 2016, 17. [CrossRef] [PubMed]

21. Prasad, A.S. Discovery of human zinc deficiency: Its impact on human health and disease. Adv. Nutr. 2013, 4, 176-190. [CrossRef] [PubMed]

22. Jeong, J.; Eide, D.J. The SLC39 family of zinc transporters. Mol. Asp. Med. 2013, 34, 612-619. [CrossRef] [PubMed]

23. Huang, L.; Tepaamorndech, S. The SLC30 family of zinc transporters-A review of current understanding of their biological and pathophysiological roles. Mol. Asp. Med. 2013, 34, 548-560. [CrossRef] [PubMed]

24. Lang, C.; Murgia, C.; Leong, M.; Tan, L.-W.; Perozzi, G.; Knight, D.; Ruffin, R.; Zalewski, P. Anti-inflammatory effects of zinc and alterations in zinc transporter mRNA in mouse models of allergic inflammation. Am. J. Physiol. Lung Cell. Mol. Physiol. 2007, 292, L577-L584. [CrossRef] [PubMed]

25. Subramanian Vignesh, K.; Landero Figueroa, J.A.; Porollo, A.; Caruso, J.A.; Deepe, G.S., Jr. Granulocyte macrophage-colony stimulating factor induced $\mathrm{Zn}$ sequestration enhances macrophage superoxide and limits intracellular pathogen survival. Immunity 2013, 39, 697-710. [CrossRef] [PubMed]

26. Maret, W. The function of zinc metallothionein: A link between cellular zinc and redox state. J. Nutr. 2000, 130, 1455S-1458S. [PubMed]

27. King, J.C. Zinc: An essential but elusive nutrient. Am. J. Clin. Nutr. 2011, 94, 679-684. [CrossRef] [PubMed]

28. Lu, J.; Stewart, A.J.; Sadler, P.J.; Pinheiro, T.J.; Blindauer, C.A. Albumin as a zinc carrier: Properties of its high-affinity zinc-binding site. Biochem. Soc. Trans. 2008, 36, 1317-1321. [CrossRef] [PubMed]

29. Heizmann, C.W.; Cox, J.A. New perspectives on S100 proteins: A multi-functional Ca(2+)-, $\mathrm{Zn}(2+)-$ and $\mathrm{Cu}(2+)$-binding protein family. Biometals 1998, 11, 383-397. [CrossRef] [PubMed]

30. Gilston, B.A.; Skaar, E.P.; Chazin, W.J. Binding of transition metals to S100 proteins. Sci. China Life Sci. 2016, 59, 792-801. [CrossRef] [PubMed]

31. Mocchegiani, E.; Costarelli, L.; Giacconi, R.; Cipriano, C.; Muti, E.; Malavolta, M. Zinc-binding proteins (metallothionein and alpha-2 macroglobulin) and immunosenescence. Exp. Gerontol. 2006, 41, 1094-1107. [CrossRef] [PubMed]

32. Nuttall, J.R.; Oteiza, P.I. Zinc and the aging brain. Genes Nutr. 2014, 9. [CrossRef] [PubMed]

33. DeCoursey, T.E.; Morgan, D.; Cherny, V.V. The voltage dependence of NADPH oxidase reveals why phagocytes need proton channels. Nature 2003, 422, 531-534. [CrossRef] [PubMed]

34. Hasegawa, H.; Suzuki, K.; Nakaji, S.; Sugawara, K. Effects of zinc on the reactive oxygen species generating capacity of human neutrophils and on the serum opsonic activity in vitro. Luminescence 2000, 15, 321-327. [CrossRef]

35. Brinkmann, V.; Reichard, U.; Goosmann, C.; Fauler, B.; Uhlemann, Y.; Weiss, D.S.; Weinrauch, Y.; Zychlinsky, A. Neutrophil Extracellular Traps Kill Bacteria. Science 2004, 303, 1532-1535. [CrossRef] [PubMed]

36. Haase, H.; Rink, L. Zinc signals and immune function. BioFactors 2014, 40, 27-40. [CrossRef] [PubMed]

37. Gaetke, L.M.; Frederich, R.C.; Oz, H.S.; McClain, C.J. Decreased food intake rather than zinc deficiency is associated with changes in plasma leptin, metabolic rate, and activity levels in zinc deficient rats. J. Nutr. Biochem. 2002, 13, 237-244. [CrossRef]

38. Nathan, C.; Ding, A. Nonresolving Inflammation. Cell 2010, 140, 871-882. [CrossRef] [PubMed]

39. Jarosz, M.; Olbert, M.; Wyszogrodzka, G.; Młyniec, K.; Librowski, T. Antioxidant and anti-inflammatory effects of zinc. Zinc-dependent NF- $\mathrm{BB}$ signaling. Inflammopharmacology 2017, 25, 11-24. [CrossRef] [PubMed]

40. Perkins, N.D. Integrating cell-signalling pathways with NF-kB and IKK function. Nat. Rev. Mol. Cell Biol. 2007, 8, 49-62. [CrossRef] [PubMed]

41. Foster, M.; Samman, S. Zinc and Regulation of Inflammatory Cytokines: Implications for Cardiometabolic Disease. Nutrients 2012, 4, 676-694. [CrossRef] [PubMed]

42. Haase, H.; Ober-Blöbaum, J.L.; Engelhardt, G.; Hebel, S.; Heit, A.; Heine, H.; Rink, L. Zinc Signals Are Essential for Lipopolysaccharide-Induced Signal Transduction in Monocytes. J. Immunol. 2008, 181, 6491-6502. [CrossRef] [PubMed]

43. Prasad, A.S.; Bao, B.; Beck, F.W.; Sarkar, F.H. Zinc-suppressed inflammatory cytokines by induction of A20-mediated inhibition of nuclear factor-kB. Nutrition 2011, 27, 816-823. [CrossRef] [PubMed]

44. Prasad, A.S.; Bao, B.; Beck, F.W.; Kucuk, O.; Sarkar, F.H. Antioxidant effect of zinc in humans. Free Radic. Biol. Med. 2004, 37, 1182-1190. [CrossRef] [PubMed] 
45. Brieger, A.; Rink, L.; Haase, H. Differential Regulation of TLR-Dependent MyD88 and TRIF Signaling Pathways by Free Zinc Ions. J. Immunol. 2013, 191, 1808-1817. [CrossRef] [PubMed]

46. Morgan, C.I.; Ledford, J.R.; Zhou, P.; Page, K. Zinc supplementation alters airway inflammation and airway hyperresponsiveness to a common allergen. J. Inflamm. 2011, 8, 36. [CrossRef]

47. Yan, Y.-W.; Fan, J.; Bai, S.-L.; Hou, W.-J.; Li, X.; Tong, H. Zinc Prevents Abdominal Aortic Aneurysm Formation by Induction of A20-Mediated Suppression of NF-kB Pathway. PLoS ONE 2016, 11, e0148536. [CrossRef] [PubMed]

48. Li, C.; Guo, S.; Gao, J.; Guo, Y.; Du, E.; Lv, Z.; Zhang, B. Maternal high-zinc diet attenuates intestinal inflammation by reducing DNA methylation and elevating H3K9 acetylation in the A20 promoter of offspring chicks. J. Nutr. Biochem. 2015, 26, 173-183. [CrossRef] [PubMed]

49. Bao, B.; Prasad, A.S.; Beck, F.W.J.; Fitzgerald, J.T.; Snell, D.; Bao, G.W.; Singh, T.; Cardozo, L.J. Zinc decreases C-reactive protein, lipid peroxidation, and inflammatory cytokines in elderly subjects: A potential implication of zinc as an atheroprotective agent. Am. J. Clin. Nutr. 2010, 91, 1634-1641. [CrossRef] [PubMed]

50. Von Bulow, V.; Dubben, S.; Engelhardt, G.; Hebel, S.; Plumakers, B.; Heine, H.; Rink, L.; Haase, H. Zinc-dependent suppression of TNF-alpha production is mediated by protein kinase A-induced inhibition of Raf-1, I kappa B kinase beta, and NF-kappa B. J. Immunol. 2007, 179, 4180-4186. [CrossRef] [PubMed]

51. Nishida, K.; Hasegawa, A.; Nakae, S.; Oboki, K.; Saito, H.; Yamasaki, S.; Hirano, T. Zinc transporter $\mathrm{Znt5/Slc30a5}$ is required for the mast cell-mediated delayed-type allergic reaction but not the immediate-type reaction. J. Exp. Med. 2009, 206, 1351-1364. [CrossRef] [PubMed]

52. Truong-Tran, A.Q.; Carter, J.; Ruffin, R.E.; Zalewski, P.D. The role of zinc in caspase activation and apoptotic cell death. Biometals 2001, 14, 315-330. [CrossRef] [PubMed]

53. Plum, L.M.; Rink, L.; Haase, H. The essential toxin: Impact of zinc on human health. Int. J. Environ. Res. Public Health 2010, 7, 1342-1365. [CrossRef] [PubMed]

54. Stennicke, H.R.; Salvesen, G.S. Biochemical Characteristics of Caspases-3, -6, -7, and -8. J. Biol. Chem. 1997, 272, 25719-25723. [CrossRef] [PubMed]

55. Huber, K.L.; Hardy, J.A. Mechanism of zinc-mediated inhibition of caspase-9. Protein Sci. 2012, 21, $1056-1065$. [CrossRef] [PubMed]

56. Velazquez-Delgado, E.M.; Hardy, J.A. Zinc-mediated allosteric inhibition of caspase-6. J. Biol. Chem. 2012, 287, 36000-36011. [CrossRef] [PubMed]

57. Maret, W.; Jacob, C.; Vallee, B.L.; Fischer, E.H. Inhibitory sites in enzymes: Zinc removal and reactivation by thionein. Proc. Natl. Acad. Sci. USA 1999, 96, 1936-1940. [CrossRef] [PubMed]

58. Muroi, M.; Tanamoto, K.-I. Zinc- and oxidative property-dependent degradation of pro-caspase-1 and NLRP3 by ziram in mouse macrophages. Toxicol. Lett. 2015, 235, 199-205. [CrossRef] [PubMed]

59. Ting, J.P.-Y.; Willingham, S.B.; Bergstralh, D.T. NLRs at the intersection of cell death and immunity. Nat. Rev. Immunol. 2008, 8, 372-379. [CrossRef] [PubMed]

60. Liu, M.-J.; Bao, S.; Galvez-Peralta, M.; Pyle, C.J.; Rudawsky, A.C.; Pavlovicz, R.E.; Killilea, D.W.; Li, C.; Nebert, D.W.; Wewers, M.D.; et al. ZIP8 regulates host defense through zinc-mediated inhibition of NF-kappaB. Cell Rep. 2013, 3, 386-400. [CrossRef] [PubMed]

61. Marreiro, D.D.N.; Cruz, K.J.C.; Morais, J.B.S.; Beserra, J.B.; Severo, J.S.; de Oliveira, A.R.S. Zinc and Oxidative Stress: Current Mechanisms. Antioxidants 2017, 6, 24. [CrossRef] [PubMed]

62. Valko, M.; Leibfritz, D.; Moncol, J.; Cronin, M.T.; Mazur, M.; Telser, J. Free radicals and antioxidants in normal physiological functions and human disease. Int. J. Biochem. Cell Biol. 2007, 39, 44-84. [CrossRef] [PubMed]

63. Bhattacharyya, A.; Chattopadhyay, R.; Mitra, S.; Crowe, S.E. Oxidative Stress: An Essential Factor in the Pathogenesis of Gastrointestinal Mucosal Diseases. Physiol. Rev. 2014, 94, 329-354. [CrossRef] [PubMed]

64. Sharma, B.; Singh, S.; Siddiqi, N.J. Biomedical Implications of Heavy Metals Induced Imbalances in Redox Systems. BioMed Res. Int. 2014, 2014. [CrossRef] [PubMed]

65. Rahman, K. Studies on free radicals, antioxidants, and co-factors. Clin. Interv. Aging 2007, 2, $219-236$. [PubMed]

66. Prasad, A.S. Zinc: An antioxidant and anti-inflammatory agent: Role of zinc in degenerative disorders of aging. J. Trace Elem. Med. Biol. 2014, 28, 364-371. [CrossRef] [PubMed]

67. Gibbs, P.N.; Gore, M.G.; Jordan, P.M. Investigation of the effect of metal ions on the reactivity of thiol groups in human 5-aminolaevulinate dehydratase. Biochem. J. 1985, 225, 573-580. [CrossRef] [PubMed] 
68. Powell, S.R. The antioxidant properties of zinc. J. Nutr. 2000, 130, 1447S-1454S. [PubMed]

69. Prasad, A.S.; Beck, F.W.J.; Bao, B.; Fitzgerald, J.T.; Snell, D.C.; Steinberg, J.D.; Cardozo, L.J. Zinc supplementation decreases incidence of infections in the elderly: Effect of zinc on generation of cytokines and oxidative stress. Am. J. Clin. Nutr. 2007, 85, 837-844. [PubMed]

70. Kloubert, V.; Rink, L. Zinc as a micronutrient and its preventive role of oxidative damage in cells. Food Funct. 2015, 6, 3195-3204. [CrossRef] [PubMed]

71. Young, B.; Ott, L.; Kasarskis, E.; Rapp, R.; Moles, K.; Dempsey, R.J.; Tibbs, P.A.; Kryscio, R.; McClain, C. Zinc supplementation is associated with improved neurologic recovery rate and visceral protein levels of patients with severe closed head injury. J. Neurotrauma 1996, 13, 25-34. [CrossRef] [PubMed]

72. Besecker, B.Y.; Exline, M.C.; Hollyfield, J.; Phillips, G.; DiSilvestro, R.A.; Wewers, M.D.; Knoell, D.L. A comparison of zinc metabolism, inflammation, and disease severity in critically ill infected and noninfected adults early after intensive care unit admission. Am. J. Clin. Nutr. 2011, 93, 1356-1364. [CrossRef] [PubMed]

73. Costarelli, L.; Muti, E.; Malavolta, M.; Cipriano, C.; Giacconi, R.; Tesei, S.; Piacenza, F.; Pierpaoli, S.; Gasparini, N.; Faloia, E.; et al. Distinctive modulation of inflammatory and metabolic parameters in relation to zinc nutritional status in adult overweight/obese subjects. J. Nutr. Biochem. 2010, 21, 432-437. [CrossRef] [PubMed]

74. Chang, K.-L.; Hung, T.-C.; Hsieh, B.-S.; Chen, Y.-H.; Chen, T.-F.; Cheng, H.-L. Zinc at pharmacologic concentrations affects cytokine expression and induces apoptosis of human peripheral blood mononuclear cells. Nutrition 2006, 22, 465-474. [CrossRef] [PubMed]

75. Tsou, T.-C.; Chao, H.-R.; Yeh, S.-C.; Tsai, F.-Y.; Lin, H.-J. Zinc induces chemokine and inflammatory cytokine release from human promonocytes. J. Hazard. Mater. 2011, 196, 335-341. [CrossRef] [PubMed]

76. Beck, F.W.J.; Li, Y.; Bao, B.; Prasad, A.S.; Sarkar, F.H. Evidence for reprogramming global gene expression during zinc deficiency in the HUT-78 cell line. Nutrition 2006, 22, 1045-1056. [CrossRef] [PubMed]

77. Wessels, I.; Haase, H.; Engelhardt, G.; Rink, L.; Uciechowski, P. Zinc deficiency induces production of the proinflammatory cytokines IL-1beta and TNFalpha in promyeloid cells via epigenetic and redox-dependent mechanisms. J. Nutr. Biochem. 2013, 24, 289-297. [CrossRef] [PubMed]

78. Prasad, A.S.; Beck, F.W.; Grabowski, S.M.; Kaplan, J.; Mathog, R.H. Zinc deficiency: Changes in cytokine production and T-cell subpopulations in patients with head and neck cancer and in noncancer subjects. Proc. Assoc. Am. Physicians 1997, 109, 68-77. [PubMed]

79. Prasad, A.S.; Bao, B.; Beck, F.W.J.; Sarkar, F.H. Correction of interleukin-2 gene expression by in vitro zinc addition to mononuclear cells from zinc-deficient human subjects: A specific test for zinc deficiency in humans. Transl. Res. J. Lab. Clin. Med. 2006, 148, 325-333. [CrossRef] [PubMed]

80. Pinna, K.; Kelley, D.S.; Taylor, P.C.; King, J.C. Immune functions are maintained in healthy men with low zinc intake. J. Nutr. 2002, 132, 2033-2036. [PubMed]

81. Kahmann, L.; Uciechowski, P.; Warmuth, S.; Plumakers, B.; Gressner, A.M.; Malavolta, M.; Mocchegiani, E.; Rink, L. Zinc supplementation in the elderly reduces spontaneous inflammatory cytokine release and restores T cell functions. Rejuvenation Res. 2008, 11, 227-237. [CrossRef] [PubMed]

82. Wong, C.P.; Rinaldi, N.A.; Ho, E. Zinc deficiency enhanced inflammatory response by increasing immune cell activation and inducing IL6 promoter demethylation. Mol. Nutr. Food Res. 2015, 59, 991-999. [CrossRef] [PubMed]

83. Prasad, A.S. Zinc: Mechanisms of Host Defense. J. Nutr. 2007, 137, 1345-1349. [PubMed]

84. Beck, F.W.; Prasad, A.S.; Kaplan, J.; Fitzgerald, J.T.; Brewer, G.J. Changes in cytokine production and T cell subpopulations in experimentally induced zinc-deficient humans. Am. J. Physiol. 1997, 272, E1002-E1007. [PubMed]

85. Tapazoglou, E.; Prasad, A.S.; Hill, G.; Brewer, G.J.; Kaplan, J. Decreased natural killer cell activity in patients with zinc deficiency with sickle cell disease. J. Lab. Clin. Med. 1985, 105, 19-22. [PubMed]

86. Honscheid, A.; Rink, L.; Haase, H. T-lymphocytes: A target for stimulatory and inhibitory effects of zinc ions. Endocr. Metab. Immune Disord. Drug Targets 2009, 9, 132-144. [CrossRef] [PubMed]

87. Wellinghausen, N.; Martin, M.; Rink, L. Zinc inhibits interleukin-1-dependent T cell stimulation. Eur. J. Immunol. 1997, 27, 2529-2535. [CrossRef] [PubMed]

88. Rosenkranz, E.; Hilgers, R.-D.; Uciechowski, P.; Petersen, A.; Plumakers, B.; Rink, L. Zinc enhances the number of regulatory $\mathrm{T}$ cells in allergen-stimulated cells from atopic subjects. Eur. J. Nutr. 2017, 56, 557-567. [CrossRef] [PubMed] 
89. Rosenkranz, E.; Maywald, M.; Hilgers, R.-D.; Brieger, A.; Clarner, T.; Kipp, M.; Plümäkers, B.; Meyer, S.; Schwerdtle, T.; Rink, L. Induction of regulatory T cells in Th1-/Th17-driven experimental autoimmune encephalomyelitis by zinc administration. J. Nutr. Biochem. 2016, 29, 116-123. [CrossRef] [PubMed]

90. Maywald, M.; Meurer, S.K.; Weiskirchen, R.; Rink, L. Zinc supplementation augments TGF- $\beta 1$-dependent regulatory T cell induction. Mol. Nutr. Food Res. 2017, 61. [CrossRef] [PubMed]

91. Rosenkranz, E.; Metz, C.H.; Maywald, M.; Hilgers, R.; Weßels, I.; Senff, T.; Haase, H.; Jäger, M.; Ott, M.; Aspinall, R.; et al. Zinc supplementation induces regulatory T cells by inhibition of Sirt-1 deacetylase in mixed lymphocyte cultures. Mol. Nutr. Food Res. 2016, 60. [CrossRef] [PubMed]

92. Hennigar, S.R.; McClung, J.P. Nutritional Immunity. Am. J. Lifestyle Med. 2016, 10, 170-173. [CrossRef]

93. Aydemir, T.B.; Chang, S.-M.; Guthrie, G.J.; Maki, A.B.; Ryu, M.-S.; Karabiyik, A.; Cousins, R.J. Zinc transporter ZIP14 functions in hepatic zinc, iron and glucose homeostasis during the innate immune response (endotoxemia). PLoS ONE 2012, 7, e48679. [CrossRef]

94. Glaser, R.; Harder, J.; Lange, H.; Bartels, J.; Christophers, E.; Schroder, J.-M. Antimicrobial psoriasin (S100A7) protects human skin from Escherichia coli infection. Nat. Immunol. 2005, 6, 57-64. [CrossRef] [PubMed]

95. Corbin, B.D.; Seeley, E.H.; Raab, A.; Feldmann, J.; Miller, M.R.; Torres, V.J.; Anderson, K.L.; Dattilo, B.M.; Dunman, P.M.; Gerads, R.; et al. Metal chelation and inhibition of bacterial growth in tissue abscesses. Science 2008, 319, 962-965. [CrossRef] [PubMed]

96. Botella, H.; Stadthagen, G.; Lugo-Villarino, G.; Chastellier, C.; de Neyrolles, O. Metallobiology of host-pathogen interactions: An intoxicating new insight. Trends Microbiol. 2012, 20, 106-112. [CrossRef] [PubMed]

97. Lappann, M.; Danhof, S.; Guenther, F.; Olivares-Florez, S.; Mordhorst, I.L.; Vogel, U. In vitro resistance mechanisms of Neisseria meningitidis against neutrophil extracellular traps. Mol. Microbiol. 2013, 89, 433-449. [CrossRef] [PubMed]

98. Stork, M.; Grijpstra, J.; Bos, M.P.; Manas Torres, C.; Devos, N.; Poolman, J.T.; Chazin, W.J.; Tommassen, J. Zinc piracy as a mechanism of Neisseria meningitidis for evasion of nutritional immunity. PLoS Pathog. 2013, 9, e1003733. [CrossRef] [PubMed]

99. Bobrov, A.G.; Kirillina, O.; Fetherston, J.D.; Miller, M.C.; Burlison, J.A.; Perry, R.D. The Yersinia pestis siderophore, yersiniabactin, and the ZnuABC system both contribute to zinc acquisition and the development of lethal septicaemic plague in mice. Mol. Microbiol. 2014, 93, 759-775. [CrossRef] [PubMed]

100. Liu, J.Z.; Jellbauer, S.; Poe, A.J.; Ton, V.; Pesciaroli, M.; Kehl-Fie, T.E.; Restrepo, N.A.; Hosking, M.P.; Edwards, R.A.; Battistoni, A.; et al. Zinc sequestration by the neutrophil protein calprotectin enhances Salmonella growth in the inflamed gut. Cell Host Microbe 2012, 11, 227-239. [CrossRef] [PubMed]

101. Nowak, J.E.; Harmon, K.; Caldwell, C.C.; Wong, H.R. Prophylactic zinc supplementation reduces bacterial load and improves survival in a murine model of sepsis. Pediatr. Crit. Care Med. 2012, 13, e323-e329. [CrossRef] [PubMed]

102. Singh, M.; Das, R.R. Zinc for the common cold. Cochrane Database Syst. Rev. 2013, CD001364. [CrossRef]

103. Mezzetti, A.; Pierdomenico, S.D.; Costantini, F.; Romano, F.; de Cesare, D.; Cuccurullo, F.; Imbastaro, T.; Riario-Sforza, G.; Di Giacomo, F.; Zuliani, G.; et al. Copper/zinc ratio and systemic oxidant load: Effect of aging and aging-related degenerative diseases. Free Radic. Biol. Med. 1998, 25, 676-681. [CrossRef]

104. Kozlowski, H.; Luczkowski, M.; Remelli, M.; Valensin, D. Copper, zinc and iron in neurodegenerative diseases (Alzheimer's, Parkinson's and prion diseases). Coord. Chem. Rev. 2012, 256, 2129-2141. [CrossRef]

105. Malavolta, M.; Giacconi, R.; Piacenza, F.; Santarelli, L.; Cipriano, C.; Costarelli, L.; Tesei, S.; Pierpaoli, S.; Basso, A.; Galeazzi, R.; et al. Plasma copper/zinc ratio: An inflammatory/nutritional biomarker as predictor of all-cause mortality in elderly population. Biogerontology 2010, 11, 309-319. [CrossRef] [PubMed]

106. Overbeck, S.; Rink, L.; Haase, H. Modulating the immune response by oral zinc supplementation: A single approach for multiple diseases. Arch. Immunol. Ther. Exp. 2008, 56, 15-30. [CrossRef] [PubMed]

107. Hulisz, D. Efficacy of zinc against common cold viruses: An overview. J. Am. Pharm. Assoc. 2004, 44, 594-603. [CrossRef]

108. Kurugol, Z.; Akilli, M.; Bayram, N.; Koturoglu, G. The prophylactic and therapeutic effectiveness of zinc sulphate on common cold in children. Acta Paediatr. 2006, 95, 1175-1181. [CrossRef] [PubMed]

109. Baum, M.K.; Lai, S.; Sales, S.; Page, J.B.; Campa, A. Randomized Controlled Clinical Trial of Zinc Supplementation to Prevent Immunological Failure in HIV-Positive Adults1,2. Clin. Infect. Dis. 2010, 50, 1653-1660. [CrossRef] [PubMed] 
110. Asdamongkol, N.; Phanachet, P.; Sungkanuparph, S. Low Plasma Zinc Levels and Immunological Responses to Zinc Supplementation in HIV-Infected Patients with Immunological Discordance after Antiretroviral Therapy. Jpn. J. Infect. Dis. 2013, 66, 469-474. [CrossRef] [PubMed]

111. Lodha, R.; Shah, N.; Mohari, N.; Mukherjee, A.; Vajpayee, M.; Singh, R.; Singla, M.; Saini, S.; Bhatnagar, S.; Kabra, S.K. Immunologic effect of zinc supplementation in HIV-infected children receiving highly active antiretroviral therapy: A randomized, double-blind, placebo-controlled trial. J. Acquir. Immune Defic. Syndr. 2014, 66, 386-392. [CrossRef] [PubMed]

112. Mocchegiani, E.; Veccia, S.; Ancarani, F.; Scalise, G.; Fabris, N. Benefit of oral zinc supplementation as an adjunct to zidovudine (AZT) therapy against opportunistic infections in AIDS. Int. J. Immunopharmacol. 1995, 17, 719-727. [CrossRef]

113. Zazzo, J.F.; Rouveix, B.; Rajagopalon, P.; Levacher, M.; Girard, P.M. Effect of zinc on the immune status of zinc-depleted AIDS related complex patients. Clin. Nutr. 1989, 8, 259-261. [CrossRef]

114. Bobat, R.; Coovadia, H.; Stephen, C.; Naidoo, K.L.; McKerrow, N.; Black, R.E.; Moss, W.J. Safety and efficacy of zinc supplementation for children with HIV-1 infection in South Africa: A randomised double-blind placebo-controlled trial. Lancet 2005, 366, 1862-1867. [CrossRef]

115. Green, J.A.; Lewin, S.R.; Wightman, F.; Lee, M.; Ravindran, T.S.; Paton, N.I. A randomised controlled trial of oral zinc on the immune response to tuberculosis in HIV-infected patients. Int. J. Tuberc. Lung Dis. 2005, 9, 1378-1384. [PubMed]

116. Fawzi, W.W.; Villamor, E.; Msamanga, G.I.; Antelman, G.; Aboud, S.; Urassa, W.; Hunter, D. Trial of zinc supplements in relation to pregnancy outcomes, hematologic indicators, and $\mathrm{T}$ cell counts among HIV-1-infected women in Tanzania. Am. J. Clin. Nutr. 2005, 81, 161-167. [PubMed]

117. Villamor, E.; Aboud, S.; Koulinska, I.N.; Kupka, R.; Urassa, W.; Chaplin, B.; Msamanga, G.; Fawzi, W.W. Zinc supplementation to HIV-1-infected pregnant women: Effects on maternal anthropometry, viral load, and early mother-to-child transmission. Eur. J. Clin. Nutr. 2006, 60, 862-869. [CrossRef] [PubMed]

118. Deloria-Knoll, M.; Steinhoff, M.; Semba, R.D.; Nelson, K.; Vlahov, D.; Meinert, C.L. Effect of zinc and vitamin A supplementation on antibody responses to a pneumococcal conjugate vaccine in HIV-positive injection drug users: A randomized trial. Vaccine 2006, 24, 1670-1679. [CrossRef] [PubMed]

119. Kawaguchi, T.; Nagao, Y.; Abe, K.; Imazeki, F.; Honda, K.; Yamasaki, K.; Miyanishi, K.; Taniguchi, E.; Kakuma, T.; Kato, J.; et al. Effects of branched-chain amino acids and zinc-enriched nutrients on prognosticators in HCV-infected patients: A multicenter randomized controlled trial. Mol. Med. Rep. 2015, 11, 2159-2166. [CrossRef] [PubMed]

120. Murakami, Y.; Koyabu, T.; Kawashima, A.; Kakibuchi, N.; Kawakami, T.; Takaguchi, K.; Kita, K.; Okita, M. Zinc supplementation prevents the increase of transaminase in chronic hepatitis $\mathrm{C}$ patients during combination therapy with pegylated interferon alpha- $2 b$ and ribavirin. J. Nutr. Sci. Vitaminol. 2007, 53, 213-218. [CrossRef] [PubMed]

121. Takagi, H.; Nagamine, T.; Abe, T.; Takayama, H.; Sato, K.; Otsuka, T.; Kakizaki, S.; Hashimoto, Y.; Matsumoto, T.; Kojima, A.; et al. Zinc supplementation enhances the response to interferon therapy in patients with chronic hepatitis C. J. Viral Hepat. 2001, 8, 367-371. [CrossRef] [PubMed]

122. Ko, W.-S.; Guo, C.-H.; Hsu, G.-S.W.; Chiou, Y.-L.; Yeh, M.-S.; Yaun, S.-R. The effect of zinc supplementation on the treatment of chronic hepatitis $C$ patients with interferon and ribavirin. Clin. Biochem. 2005, 38, 614-620. [CrossRef] [PubMed]

123. Hoque, K.M.; Binder, H.J. Zinc in the treatment of acute diarrhea: Current status and assessment. Gastroenterology 2006, 130, 2201-2205. [CrossRef] [PubMed]

124. Dutta, P.; Mitra, U.; Dutta, S.; Naik, T.N.; Rajendran, K.; Chatterjee, M.K. Zinc, vitamin A, and micronutrient supplementation in children with diarrhea: A randomized controlled clinical trial of combination therapy versus monotherapy. J. Pediatr. 2011, 159, 633-637. [CrossRef] [PubMed]

125. Malik, A.; Taneja, D.K.; Devasenapathy, N.; Rajeshwari, K. Zinc supplementation for prevention of acute respiratory infections in infants: A randomized controlled trial. Indian Pediatr. 2014, 51, 780-784. [CrossRef] [PubMed]

126. Shah, U.H.; Abu-Shaheen, A.K.; Malik, M.A.; Alam, S.; Riaz, M.; AL-Tannir, M.A. The efficacy of zinc supplementation in young children with acute lower respiratory infections: A randomized double-blind controlled trial. Clin. Nutr. 2013, 32, 193-199. [CrossRef] [PubMed] 
127. Martinez-Estevez, N.S.; Alvarez-Guevara, A.N.; Rodriguez-Martinez, C.E. Effects of zinc supplementation in the prevention of respiratory tract infections and diarrheal disease in Colombian children: A 12-month randomised controlled trial. Allergol. Immunopathol. 2016, 44, 368-375. [CrossRef] [PubMed]

128. Sazawal, S.; Black, R.E.; Jalla, S.; Mazumdar, S.; Sinha, A.; Bhan, M.K. Zinc supplementation reduces the incidence of acute lower respiratory infections in infants and preschool children: A double-blind, controlled trial. Pediatrics 1998, 102, 1-5. [CrossRef] [PubMed]

129. Mahalanabis, D.; Lahiri, M.; Paul, D.; Gupta, S.; Gupta, A.; Wahed, M.A.; Khaled, M.A. Randomized, double-blind, placebo-controlled clinical trial of the efficacy of treatment with zinc or vitamin A in infants and young children with severe acute lower respiratory infection. Am. J. Clin. Nutr. 2004, 79, 430-436. [PubMed]

130. Karyadi, E.; West, C.E.; Schultink, W.; Nelwan, R.H.H.; Gross, R.; Amin, Z.; Dolmans, W.M.V.; Schlebusch, H.; van der Meer, J.W.M. A double-blind, placebo-controlled study of vitamin A and zinc supplementation in persons with tuberculosis in Indonesia: Effects on clinical response and nutritional status. Am. J. Clin. Nutr. 2002, 75, 720-727. [PubMed]

131. Mathur, N.K.; Bumb, R.A.; Mangal, H.N. Oral zinc in recurrent Erythema Nodosum Leprosum reaction. Lepr. India 1983, 55, 547-552. [PubMed]

132. Mathur, N.K.; Bumb, R.A.; Mangal, H.N.; Sharma, M.L. Oral zinc as an adjunct to dapsone in lepromatous leprosy. Int. J. Lepr. Other Mycobact. Dis. Off. Org. Int. Lepr. Assoc. 1984, 52, 331-338.

133. El-Shafei, M.M.; Kamal, A.A.; Soliman, H.; el-Shayeb, F.; Abdel Baqui, M.S.; Faragalla, S.; Sabry, M.K. Effect of oral zinc supplementation on the cell mediated immunity in lepromatous leprosy. J. Egypt. Public Health Assoc. 1988, 63, 311-336. [PubMed]

134. Mahajan, P.M.; Jadhav, V.H.; Patki, A.H.; Jogaikar, D.G.; Mehta, J.M. Oral zinc therapy in recurrent erythema nodosum leprosum: A clinical study. Indian J. Lepr. 1994, 66, 51-57. [PubMed]

135. Alam, A.N.; Sarker, S.A.; Wahed, M.A.; Khatun, M.; Rahaman, M.M. Enteric protein loss and intestinal permeability changes in children during acute shigellosis and after recovery: Effect of zinc supplementation. Gut 1994, 35, 1707-1711. [CrossRef] [PubMed]

136. Raqib, R.; Roy, S.K.; Rahman, M.J.; Azim, T.; Ameer, S.S.; Chisti, J.; Andersson, J. Effect of zinc supplementation on immune and inflammatory responses in pediatric patients with shigellosis. Am. J. Clin. Nutr. 2004, 79, 444-450. [PubMed]

137. Rahman, M.J.; Sarker, P.; Roy, S.K.; Ahmad, S.M.; Chisti, J.; Azim, T.; Mathan, M.; Sack, D.; Andersson, J.; Raqib, R. Effects of zinc supplementation as adjunct therapy on the systemic immune responses in shigellosis. Am. J. Clin. Nutr. 2005, 81, 495-502. [PubMed]

138. Roy, S.K.; Raqib, R.; Khatun, W.; Azim, T.; Chowdhury, R.; Fuchs, G.J.; Sack, D.A. Zinc supplementation in the management of shigellosis in malnourished children in Bangladesh. Eur. J. Clin. Nutr. 2008, 62, 849-855. [CrossRef] [PubMed]

139. Kashimura, H.; Suzuki, K.; Hassan, M.; Ikezawa, K.; Sawahata, T.; Watanabe, T.; Nakahara, A.; Mutoh, H.; Tanaka, N. Polaprezinc, a mucosal protective agent, in combination with lansoprazole, amoxycillin and clarithromycin increases the cure rate of Helicobacter pylori infection. Aliment. Pharmacol. Ther. 1999, 13, 483-487. [CrossRef] [PubMed]

140. Zeba, A.N.; Sorgho, H.; Rouamba, N.; Zongo, I.; Rouamba, J.; Guiguemdé, R.T.; Hamer, D.H.; Mokhtar, N.; Ouedraogo, J.-B. Major reduction of malaria morbidity with combined vitamin A and zinc supplementation in young children in Burkina Faso: A randomized double blind trial. Nutr. J. 2008, 7, 7. [CrossRef] [PubMed]

141. Shankar, A.H.; Genton, B.; Baisor, M.; Paino, J.; Tamja, S.; Adiguma, T.; Wu, L.; Rare, L.; Bannon, D.; Tielsch, J.M.; et al. The influence of zinc supplementation on morbidity due to Plasmodium falciparum: A randomized trial in preschool children in Papua New Guinea. Am. J. Trop. Med. Hyg. 2000, 62, 663-669. [CrossRef] [PubMed]

142. Bates, C.J.; Evans, P.H.; Dardenne, M.; Prentice, A.; Lunn, P.G.; Northrop-Clewes, C.A.; Hoare, S.; Cole, T.J.; Horan, S.J.; Longman, S.C. A trial of zinc supplementation in young rural Gambian children. Br. J. Nutr. 1993, 69, 243-255. [CrossRef] [PubMed]

143. Muller, O.; Becher, H.; van Zweeden, A.B.; Ye, Y.; Diallo, D.A.; Konate, A.T.; Gbangou, A.; Kouyate, B.; Garenne, M. Effect of zinc supplementation on malaria and other causes of morbidity in west African children: Randomised double blind placebo controlled trial. BMJ Clin. Res. 2001, 322, 1567. [CrossRef] 
144. Zinc Against Plasmodium Study Group. Effect of zinc on the treatment of Plasmodium falciparum malaria in children: A randomized controlled trial. Am. J. Clin. Nutr. 2002, 76, 805-812.

145. Richard, S.A.; Zavaleta, N.; Caulfield, L.E.; Black, R.E.; Witzig, R.S.; Shankar, A.H. Zinc and iron supplementation and malaria, diarrhea, and respiratory infections in children in the Peruvian Amazon. Am. J. Trop. Med. Hyg. 2006, 75, 126-132. [PubMed]

146. Lazzerini, M.; Wanzira, H. Oral zinc for treating diarrhoea in children. Cochrane Database Syst. Rev. 2016. [CrossRef]

147. World Health Organisation. Zinc Supplementation in the Management of Diarrhoea; World Health Organisation: Geneva, Switzerland, 2017.

148. Finamore, A.; Massimi, M.; Conti Devirgiliis, L.; Mengheri, E. Zinc deficiency induces membrane barrier damage and increases neutrophil transmigration in Caco-2 cells. J. Nutr. 2008, 138, 1664-1670. [PubMed]

149. Bao, S.; Knoell, D.L. Zinc modulates cytokine-induced lung epithelial cell barrier permeability. Am. J. Physiol. Lung Cell. Mol. Physiol. 2006, 291, L1132-41. [CrossRef] [PubMed]

150. Lansdown, A.B.G.; Mirastschijski, U.; Stubbs, N.; Scanlon, E.; Agren, M.S. Zinc in wound healing: Theoretical, experimental, and clinical aspects. Wound Repair Regen. 2007, 15, 2-16. [CrossRef] [PubMed]

151. Gosain, A.; DiPietro, L.A. Aging and Wound Healing. World J. Surg. 2004, 28, 321-326. [CrossRef] [PubMed]

152. Lu, X.; Wang, M.; Qi, J.; Wang, H.; Li, X.; Gupta, D.; Dziarski, R. Peptidoglycan Recognition Proteins Are a New Class of Human Bactericidal Proteins. J. Biol. Chem. 2006, 281, 5895-5907. [CrossRef] [PubMed]

153. Wang, M.; Liu, L.-H.; Wang, S.; Li, X.; Lu, X.; Gupta, D.; Dziarski, R. Human Peptidoglycan Recognition Proteins Require Zinc to Kill Both Gram-Positive and Gram-Negative Bacteria and Are Synergistic with Antibacterial Peptides. J. Immunol. 2007, 178, 3116-3125. [CrossRef] [PubMed]

(C) 2017 by the authors. Licensee MDPI, Basel, Switzerland. This article is an open access article distributed under the terms and conditions of the Creative Commons Attribution (CC BY) license (http:/ / creativecommons.org/licenses/by/4.0/). 